NBER WORKING PAPER SERIES

\title{
COLONIALISM AND MODERN INCOME - ISLANDS AS NATURAL EXPERIMENTS
}

\author{
James Feyrer \\ Bruce Sacerdote \\ Working Paper 12546 \\ http://www.nber.org/papers/w12546
}

\author{
NATIONAL BUREAU OF ECONOMIC RESEARCH \\ 1050 Massachusetts Avenue \\ Cambridge, MA 02138 \\ September 2006
}

We thank Lauren Burrows, Katie Jaxheimer, and Celia Carmen for superb research assistance and the National Science Foundation for generous support. The views expressed herein are those of the author(s) and do not necessarily reflect the views of the National Bureau of Economic Research.

(C2006 by James Feyrer and Bruce Sacerdote. All rights reserved. Short sections of text, not to exceed two paragraphs, may be quoted without explicit permission provided that full credit, including $\odot$ notice, is given to the source. 
Colonialism and Modern Income - Islands as Natural Experiments

James Feyrer and Bruce Sacerdote

NBER Working Paper No. 12546

September 2006

JEL No. E21, O11, O4, O40

\begin{abstract}
Using a new database of islands throughout the Atlantic, Pacific and Indian Oceans we examine whether colonial origins affect modern economic outcomes. We argue that the nature of discovery and colonization of islands provides random variation in the length and type of colonial experience. We instrument for length of colonization using wind direction and wind speed. Wind patterns which mattered a great deal during the age of sail do not have a direct effect on GDP today, but do affect GDP via their historical impact on colonization. The number of years spent as a European colony is strongly positively related to the island's GDP per capita and negatively related to infant mortality. This basic relationship is also found to hold for a standard dataset of developing countries. We test whether this link is directly related to democratic institutions, trade, and the identity of the colonizing nation. While there is substantial variation in the history of democratic institutions across the islands, such variation does not predict income. Islands with significant export products during the colonial period are wealthier today, but this does not diminish the importance of colonial tenure. The timing of the colonial experience seems to matter. Time spent as a colony after 1700 is more beneficial to modern income than years before 1700 , consistent with a change in the nature of colonial relationships over time.
\end{abstract}

James Feyrer

Dartmouth College

6106 Rockefeller Center

Hanover, NH 03755-3514

james.feyrer@dartmouth.edu

Bruce Sacerdote

6106 Rockefeller Hall

Department of Economics

Dartmouth College

Hanover, NH 03755-3514

and NBER

Bruce.I.Sacerdote@dartmouth.edu 


\section{Introduction}

Understanding the variation in income across countries remains one of economics' most important research questions. Many authors have explored the links between colonialism and modern day outcomes, though little consensus exists. Historians and political scientists have emphasized the long term negative consequences of colonial rule including the possible inability of former colonies to transition to a stable form of self government or the possible negative effects of resource extraction (see for example Rodney [1974]). In this paper we show that time spent as a colony is strongly positively correlated with modern economic outcomes across islands.

Recent economic work on the importance of institutions has shifted the focus of empirical growth toward colonialism. La Porta, Lopez de Silanes, Shleifer and Vishny [1997, 1998] show that former colonies of English common law countries have more developed capital markets than former colonies with French civil law. Banerjee and Iyer [2005] look at the effect of differences in colonial property rights institutions in India. Acemoglu, Johnson and Robinson [2001, 2002] show that the form of colonization (extractive versus heavy settlement by Europeans) tended to determine the type of institutions created in the country and therefore strongly affected modern outcomes.

Obviously causality is problematic in considering the effect of institutions on growth. Glaeser, La Porta, Lopez de Silanes, Shleifer and Vishny [2004] argue that human capital causes growth and rich countries then adopt good institutions. The literature has attempted to deal with this through the use of instrumental variables, but finding appropriate instruments is difficult. Mauro [1995] uses ethnolinguistic fractionalization to instrument for corruption. Hall and Jones [1999] use the distance from the equator as an instrument, arguing that this determines the degree of European influence. In neither case is it clear that the instrument does not have a direct effect on output. In a paper focusing on Indian states, Iyer [2005] uses the deaths of rulers lacking male heirs as an instrument for the degree of British colonial control. Acemoglu, Johnson, and Robinson [2001, 2002] argue that the death rates of settlers provide a useful instrument for modern 
institutions. This approach has not been without critics. McArthur and Sachs [2000] argue that settler mortality is related to the overall disease environment and has a direct effect on output.

We bring two innovations to this debate. First, we have created a new database of 80 islands which contains a large number of additional data points beyond the usual cross section of countries used by growth economists. Of the 136 countries in the Penn World Tables with GDP data for 1989 only 13 are in our database. ${ }^{2}$ Islands provide an interesting experiment in that our sample has more homogenous initial conditions than the Penn World Tables group. We will also argue that variation in the colonial experience of islands was relatively random and therefore constitutes a natural experiment.

In order to check this conjecture, we propose and implement a new source of exogenous variation in colonial history - wind patterns. Wind speed and direction were crucial during the age of sail, and have useful variation within each ocean and within a given latitude. Islands located near routes in the prevailing winds made useful stopovers and were more easily revisited and colonized. However, since the beginning of the age of steam began over 100 years ago, the importance of wind patterns has disappeared. We argue that any effect of wind speed on current GDP works only through wind's effect on European settlement.

We show that the length of colonial period is strongly positively related to modern outcomes. In order to asses the randomness of the colonial experience (colonizers may settle the best places first and give them up last), we instrument for the year of European discovery and subsequent length of colonial period using data on wind patterns. The IV results are nearly identical to the OLS results, which is consistent with our conjecture that much of the variation in the colonization of islands is random.

\footnotetext{
${ }^{2}$ Barbados, Comoros, Dominican Republic, Fiji, Haiti, Jamaica, St. Kitts and Nevis, Mauritius, Philippines, Seychelles, Trinidad and Tobago, Puerto Rico, Vanuatu
} 
Like Acemoglu et al, our work suggests that differences in European settlement play an important role in determining modern output. However, our initial results differ in that the length of time, not the type of settlement is what matters. It may be that these effects are related, so we attempt to distinguish between them by examining some of the colonial era institutional features of the islands. First, we examine the hypothesis that colonization raised income via the introduction of trade. Islands whose primary colonial exports involved intensive agriculture or complex extraction fare somewhat better in modern times than islands whose main exports were dried coconut or fish. The trade results, however, do not significantly diminish the impact of the length of colonization.

Another institutional feature that is often suggested is democracy. We look at the first date that each island has an elected legislature (including colonial legislatures). By this measure, there is substantial variation in when the various islands obtained democratic institutions. Former Spanish colonies were the slowest to have a democratically elected legislature and former British island colonies were the fastest. However, this measure of democratic institutions is not a significant predictor of modern output in our sample.

Next, we use colonial dependence on slave labor and the modern ethnic composition of the population as a measure of the type of colonial regime. Acemoglu et al. find that the difference between settlement and extractive colonial regimes is important for explaining modern outcomes. We find no significant difference between colonies with imported slaves and those without and we find no relationship between modern ethnic composition and output.

We also examine more basic facts about the colonial experience. La Porta, Lopez de Silanes, Shleifer and Vishny [1997, 1998] show that legal origin of the colonizers is related to capital market size, with former colonies of English common law countries having more developed capital markets than those with French civil law. We do not find a significant difference between colonizers using the two different legal systems. 
We do, however, find significant differences between colonizers. An additional year as a colony of the US is associated with a significantly larger increase in GDP than any other country. The Dutch, British, and French are next best and there are no significant differences between them. Years as a Spanish colony are still positively associated with income, but somewhat less so than the previous group. Unique among the European colonizers, years spent as a Portuguese colony are negatively associated with modern GDP. However, there are only two Portuguese colonies in our dataset and they were all very early colonies.

The final difference that we consider is the timing of the colonial period. The historical record suggests that pre-Enlightenment colonialism had a much different attitude toward natives than post-Enlightenment colonialism. The records of the voyage of Magellan in the $16^{\text {th }}$ century versus those of James Cook in the $19^{\text {th }}$ suggest that the Europeans took on a much more benevolent attitude toward native peoples during the latter period. Indeed we find that years spent as a colony after 1700 are driving our results. These latter years are significantly associated with modern income while pre 1700 years of colonialism have no effect.

The fact that events centuries past exert a modern influence suggests the importance of institutions. Viewed in this way, our results may be most related to Hall and Jones [1999], who use geographical instruments to suggest that "social infrastructure," or broadly construed institutions, explain much of modern outcomes. They find that the quality of institutions is a result of European influence. We advance on their findings in several important ways. First, we can much more cleanly identify the effect of European influence through the use of wind as an instrument. The IV results suggest that the colonial experiences of our island sample constitute something of a natural experiment.

Simple institutional features such as trade, democracy, and slavery do not seem to be driving our results. However, differences associated with the identity and timing of the colonizers do suggest that there is heterogeneity in the colonial legacy. Acemoglu et al suggest that modern institutional quality is a direct function of the quality of colonial 
institutions. Our results can certainly be viewed through this lens. Readers of the historical record will be unsurprised that we find the US and Dutch to be more beneficial colonizers than the Spanish and Portuguese or that $18^{\text {th }}$ century colonialism is different from $16^{\text {th }}$ century colonialism. However, this heterogeneity does not diminish the central result that a longer experience with Europeans is associated with higher income. ${ }^{3}$

\section{Islands as Natural Experiments and the Importance of Wind}

\section{II.A. The Random Component of Island Settlement}

The exploration and settlement of islands in the Pacific, Atlantic and Indian Oceans entails hundreds of fascinating stories and historical accidents. At the broadest level, the pattern of island discovery by Europeans makes a great deal of economic sense. Most of the Caribbean islands were known to Europeans prior to most of the Pacific Islands. This was a matter of distance from Europe and the incredible vastness of the Pacific. For example, Columbus sighted the British Virgin Islands in 1493 and he had already sighted portions of the Bahamas, Hispaniola and Cuba a year before that. Of the 39 Atlantic islands in our database, 24 were first sighted by Columbus during one of his three voyages. By 1685 the Dutch were using St. Thomas (Virgin Islands) as a slave trading post and the island contained large sugar plantations by the mid 1700s.

Meanwhile, certain islands in the Pacific (in French Polynesia and the Cook Islands in particular) were not sighted by Europeans until the late 1700s. Patterns of settlement were determined in part by obvious economic factors like distance to the mainland. However, a fair amount of colonization was due to unique historical accidents and due to historical trade routes and wind patterns.

The Mutiny on the Bounty itself led to the discovery of several islands and the colonization of at least two. While fleeing Tahiti, the mutineers discovered Rarotonga in the Cook Islands. Captain Bligh discovered Kadavu in Fiji as he sailed his open boat 3,600 miles from the Friendly Islands to Java (without losing a single one of his 18 crewmembers). The mutineers settled on Pitcairn (with their Tahitian wives) precisely

\footnotetext{
${ }^{3}$ Indeed in probably makes the finding more plausible.
} 
because no one lived there and it was not near any land mass of note. The mutineers' descendants became so numerous that the British government then moved some of them to Norfolk Island thereby creating a second new colony.

One island in our data set, Penrhyn in the Cook Islands was accidentally colonized in 1788 when Captain Sever smashed his ship (the Penryhn) into the shoreline on his way to deliver convicts to Botany Bay. Vanuatu acquired a small settlement in 1825 when one sailor discovered that it contained sandalwood, which was at that time very valuable. Palmerston was colonized by the British mostly because it was empty when Captain Cook discovered it. The first group of settlers took to murdering each other. However the second settlement was more successful; William Marsters moved there in 1862 with his three Polynesian wives and his descendants are still there.

\section{II.B. The Importance of Wind}

Though random accident played a large role, we will also argue that wind speed and direction were important factors in the pattern of island colonization. Unlike powered boats, sailboats require steady wind to make headway. Islands located in areas where the wind is weak were less likely to be discovered, revisited, and colonized by Europeans. Wind direction is also important. The technology available at the time of the voyage of Columbus only allowed ships to sail about twenty degrees into the wind. This technology improved slowly over time, but sailing into the wind remained difficult until steamships became the norm in the twentieth century. ${ }^{4}$

Consistent downwind routes between useful destinations were therefore well traveled while much of the globe went virtually untouched. Much of the east to west traffic across the Pacific after Magellan's 1521 crossing closely followed his pioneering voyage because his path was the logical and efficient way to cross. Crossing in the opposite direction turned out to be much more difficult due to prevailing wind patterns. At least

\footnotetext{
${ }^{4}$ Sailing ships were common for transoceanic voyages long after the introduction of steam powered ships because it was difficult for early steamships to carry enough fuel for long voyages. This was particularly true in the Pacific.
} 
four Spanish expeditions attempted and failed to establish a west to east route across the Pacific in the wake of Magellan's voyage. It was not until 1565 that a west to east path was found across the Pacific and this required sailing much farther north.

The net result of this history is that the pattern of colonization is related to the speed and direction of the prevailing winds. Islands like Fefan and Pohnpei in the Federated States of Micronesia have calm winds, were not located near the Spanish trade route and were basically left alone, even after their discovery in the 1680s. At the other extreme, despite also being quite isolated, Guam was directly on the Spaniard's Manila Galleon route due to a favorable combination of wind and currents. Magellan found Guam in 1521 and by the end of the century it was settled as a watering hole for Spanish ships on the MexicoPhilippines route.

Once an island was discovered, the path to European settlement was made more difficult by the crude state of mapping technology. Before the mid eighteenth century the measurement of longitude at sea was extremely imprecise. There are many cases of islands appearing multiple times on early maps because longitude was estimated differently by separate voyages. Revisiting an island charted by a previous voyage was problematic. The known map of the world at the dawn of the eighteenth century was therefore incomplete and inaccurate. Such was the state of ignorance that many still held out hope of a large undiscovered land mass in the Pacific. This changed during the latter half of the eighteenth century with the solution of the longitude problem by Harrison. James Cook and others made voyages which filled in the remaining map of the Pacific.

Latitude sailing was the most common form of navigation before the solution to the latitude problem. Suppose you were trying to sail from Europe to a particular island in the Pacific without an accurate measure of latitude. You would head north after rounding Cape Horn until the vessel was at the same latitude as the destination. This was easy and effective because the ship's latitude could be easily and accurately determined by measuring the height of the sun off the horizon at noon. Similarly, the latitude of your destination on charts was well measured even if the longitude was not. Once at the 
proper latitude, all that was needed to get to the destination was to sail due west until you arrived. In order for this strategy to work, it was important that you arrived at the target latitude to the east of your destination, forcing ships to sail north more rapidly than would be sensible on a direct route. With this style of navigation, east-west corridors with steady winds become more frequently traveled.

We propose wind speed and direction as ideal instruments for colonization and settlement. Wind was incredibly important during the age of sail, but its importance came to an abrupt halt early in the twentieth century. Thus within our sample wind direction and speed should not have a direct effect on an island's current level of GDP, but could have an important effect via the island's history of colonization. In a first stage regression, wind speed and variability are important determinants of the number of years of colonization.

\section{The Nature of Island Colonization}

In the Atlantic islands, colonization generally consisted of several hundred or a few thousand Europeans arriving and in some cases being granted large parcels of land for farming. Early Spanish colonialism was governed by the encomienda system which essentially introduced feudal institutions to the colonies. The conquistadors were given trusteeship over the native peoples. In practice, natives (mostly Arawaks or Caribs) were often enslaved to work on these plantations.

Initially the Spanish focused on extracting gold from rivers and showed reckless disregard for the natives enslaved to do the work. At its peak in 1510, Puerto Rico produced 100,000 pesos of gold, but gold production gave out completely by 1540 (Carrión [1973]). Sugar cane was introduced and soon became a chief export crop in the Caribbean islands. As early as 1550, Puerto Rico had 10 sugar mills producing 500,000 pounds of sugar a year. Coffee was introduced in Puerto Rico in 1736 and ginger and tobacco were also important crops (Carrión [1973]). 
The English and French were more enterprising than the Spaniards in setting up the sugar-slave economy and by 1673 there were 57 plantations in English controlled Barbados. Jamaica was at one point in the $17^{\text {th }}$ century (after the British captured it from the Spaniards) the world's largest producer of sugar (Black [1881]). By 1700, the French had established many sugar plantations on virtually all of their islands, including Martinique, Guadeloupe, Grenada, St. Croix, and Saint-Domingue (present day Haiti).

In the late sixteenth and early seventeenth centuries the island-colonies in the Caribbean tended to have several hundred Europeans and, following the introduction of sugar were often outnumbered by African slaves by a factor of 10 to 1 . In 1530 Puerto Rico had about 400 Spaniards and 2200 African slaves (Wagenheim [1973]). By 1789 SaintDomingue was home to 40,000 whites and 455,000 black slaves.

Colonies in the Pacific Islands tended to involve fewer numbers of Europeans and far less reliance on imported slaves. Missionaries were often the first colonial residents. For example, Guam was first sighted by Magellan in 1521. In 1668 the Spanish installed a group of Jesuit missionaries, a single garrison of soldiers and a colonial governor. The Spanish mission totaled 50 people relative to the 12,000 Chamorros on Guam. (Douglas [1994], Rogers [1995]).

European contact with and colonization of Tahiti was relatively late in coming. Wallis landed there and traded with the natives in 1767. Cook did the same two years later and then Bligh visited several times and stayed for several months. British missionaries eventually showed up around 1797 . The mission consisted initially of 18 men and 5 women and these Europeans settled on the Matavai Bay peninsula. British ships continued to stop in Tahiti with increasing frequency to take on water and food. By the census in 1848 there were about 500 white people in Tahiti (Newbury [1980]).

French missionaries arrived in New Caledonia in 1843. By 1878, the French had established a penal colony there with 6,000 white prisoners and several hundred free whites including soldiers (Lyons [1986]). Spain's colonization of the Caroline and 
Marshall Islands was extremely sparse. In 1710 two Jesuit missionaries were landed at Palau but were never seen or heard from again. The Spanish placed a handful of Capuchin monks on Yap who opened a school and managed to convert a large number of natives.

In the late nineteenth century entrepreneurial traders and employees of trading companies were also responsible for a modest presence of Europeans and Americans on some Pacific Islands. O'Keefe was an Irish-American from Georgia who ran a series of trading outposts and stores on Yap and Palau (Hezel [1995]). James Paddon, a sandalwood merchant, was one of the first white settlers in New Caledonia. In 1851, he moved his trading and shipping business to the area that became the town of Noumea.

\section{The Impact of Colonization}

\section{IV.A. Loss of Native Peoples to Disease and Slavery}

One of the most striking and terrible facts about colonization by Europeans is the degree to which native populations on some islands were decimated either by brutal enslavement or by diseases carried by Europeans and their animals (See Diamond [1997]). This is most true in the Atlantic where certain islands lost their entire native population in a short amount of time. For example, the Spaniards began to colonize Puerto Rico in 1505 under the leadership of Ponce de Leon. The native Tainos were essentially enslaved as part of the encomienda system in which land grants to Spaniards included the right to extract tribute or labor from the natives assigned to that land. The original population of Tainos was estimated to have been 60,000. By 1515 this had fallen to 14,400 and by 1530 to 1,500 (Wagenheim [1998]). Prior to the arrival of Europeans, Jamaica was heavily settled and was home to tens of thousands of Arawaks. Not a single one of the natives were alive by the time the British took over from the Spanish in 1655 (Black [1881]).

The Pacific islanders also faced shocking mortality due to smallpox and other diseases brought by the Europeans. ${ }^{5}$ However, only a few of the islands saw a complete wiping

\footnotetext{
${ }^{5}$ Venereal disease brought by the Spaniards often lead to sterilization.
} 
out of the original inhabitants and several islands fared reasonably well. Perhaps the worst depopulation occurred in Guam and the Marianas. The number of pure blooded Chamorros on Guam fell from 12,000 in 1668 to 1,576 in $1742^{6}$. By this point the Chamorros were well intermarried with Filipino and Spanish immigrant families.

The Tahitians saw a drop in their population as a result of the introduction of European disease, but this was followed by a partial recovery. One estimate puts the population of Tahiti at 24,000 around the time of Cook's visit but only 9,000-10,000 by 1800 . The native population stabilized and remained around 9,500 at the time of the 1848 census. There was a discrete drop in the 1850s (an epidemic?) but population not only recovered to the 1848 level but grew modestly for the next 60 years (Newbury [1980]).

Any discussion of the effects of colonialism on economic output has to acknowledge the devastation of native populations and cultures. Our results show that islands with a longer colonial history (and more settlement by Europeans) have higher income per capita and lower infant mortality than other similar islands. Is it sensible to measure the positive effects on growth from European contact if in fact the original inhabitants are partially or entirely wiped out because of that contact? Is the possibility of no European contact a realistic counterfactual? Even without colonialism proper, any contact still may have wiped out entire populations.

We do not intend to address these questions in this paper. Our results are simply an examination of the standard of living of people currently alive on these islands relative to the colonial experience. We do, however, recognize that there are other measures of the outcomes from colonialism that may generate different conclusions. It is certainly plausible to argue that the accumulated utility of Pacific Islanders since first encountering Europeans is lower than in the counterfactual even if the current standard of living on these islands is significantly higher because of that contact.

\footnotetext{
${ }^{6}$ Douglas [1995] notes that the population decline probably started much earlier, i.e. in 1564 when Legazpi's expedition visited the Marianas and likely introduced European diseases.
} 


\section{IV.B. Promotion of Trade and Exports}

If colonial tenure is related to modern economic outcomes, the obvious question is why? Our results and our reading of the historical record suggest a very sensible yet underdiscussed explanation: the promotion of trade. For many of the islands the very notion of households generating a surplus and exporting this surplus in exchange for money and goods arrived with the colonizers. The historical record makes it clear that colonial governments were obsessed with introducing and expanding the production of export commodities like sugar, coffee, tobacco, and even coconuts. Colonial island regimes were obsessed with "making the colony profitable" or at least self sustaining. Home governments wanted to collect more tax revenue than they were pouring into the island as subsidies. Colonial governors wanted to generate lots of cash flow from exports so that they could direct some of this cash into their pockets.

By 1510, Spain was closely monitoring production in Puerto Rico and the Crown appointed an accountant, a commissioner and a treasurer to measure production and exports and collect the appropriate duties on the King's behalf. When opportunities for extracting gold and salt ran out in 1530, Puerto Rico's Governor, Franciso Manuel de Lando seized on the idea of growing sugar for export. He convinced the Crown to provide loans to build sugar mills and to finance the voyage of families from Spain and refugees from Brazil to provide labor. Prospective plantation owners were lured from Spain with the promise of the indefinite use of large (several hundred acre) tracts of land for growing sugar (Wagenheim, p 56-57).

The Spanish colonists in Jamaica experimented with a wide variety of export crops including tobacco, indigo, and cocoa before they hit upon sugar as the real cash crop. Once the British seized Jamaica, Governor Sir Thomas Modyford (1664) immediately set about both increasing the amount of land under sugar cultivation and encouraging large scale plantation agriculture (Black [1881], pp. 89-90). 
European colonists in the Pacific Islands also focused on trade and exports. New Caledonia settlers in the 1860s initially tried growing coffee, sugar, tobacco and rice. But cattle proved the ideal product and there were more than 100,000 cattle there by 1890 ! However, the real export legacy of colonists in New Caledonia came in 1864 when Garnier discovered nickel (Lyons [1986], p. 49). New Caledonia is currently the world's fourth largest nickel producer and has about 25 percent of proven reserves. ${ }^{7} \quad$ Even very lightly settled islands of the Pacific were affected by international trade introduced by the Europeans. Copra (dried coconut) became a chief export of Yap by the 1880s and natives would haul baskets of coconuts to local trading stations. (Hezel [1995], p 19.).

\section{IV.C. Building of Schools, Roads and Public Health Infrastructure by Colonizers}

Besides the promotion of trade, colonizers also had a large hand in building schools, roads and infrastructure for drinking water. In the early colonial period, island schools were introduced and run by missionaries and were neither comprehensive (generally being grammar schools only) nor universal. San Juan, Puerto Rico had one school built by the Franciscans in 1640 and a second shortly thereafter by the local Bishop. (Wagenheim [1998], p. 74). San Juan's first high school was established in 1832 by a group of clergymen. By 1897 Puerto Rico had 551 schools and 28,000 pupils. (Wagenheim, p. 234-235.) Many early public schools in Jamaica were set up by bequests from plantation owners who wanted to benefit the island residents. The first such school opened in 1694 using a bequest from Raines Waite (Black [1881], p. 187). The first school on Guam was opened in 1873 by the missionary Father San Vitores (Rogers [1995], p. 50). Several schools on Tahiti were opened by missionaries in the late 1800s and the colonial government opened a school for teachers in 1901 (Newbury [1980], p. 150).

Universal education did not arrive in any of the island colonies until the twentieth century, but in many cases colonizers had a hand in setting up universal educational systems. After Puerto Rico became a US commonwealth, the American administration

\footnotetext{
${ }^{7}$ CIA World Factbook, minerals.usgs.gov
} 
rapidly expanded the number of rural schools. By 1920 there were 11 high schools and the University of Puerto Rico had been founded (Carrión [1983], p. 174).

\section{IV.D. Does the Enlightenment Matter? -- Magellan versus Cook}

The previous sections suggest several concrete institutional differences that may be associated with the colonial legacy. In this section we would like to suggest a more basic difference in the nature of colonial regimes -- timing. There was a distinct change in the attitude of the explorers toward the world between the beginning of the period of exploration and the final filling in of the maps of the world. To illustrate this, one need only look at the differences in motivation between Ferdinand Magellan and James Cook.

When Magellan set sail on his famous circumnavigation in 1519 his goal was to find a Spanish route to the Spice Islands. The Treaty of Tordesillas in 1494 split the world between Spain and Portugal at $46^{\circ} \mathrm{W}$ longitude. It was also agreed that this line extended completely around the globe. However, due to the inability to measure longitude accurately, the exact location of this antemeridian was uncertain. The Spanish felt that a westward route would allow them to lay claims on the Spice Islands. The agreement between Spain and Portugal had the blessing of the Pope and along with their rights to these unfound lands came a responsibility to spread Christianity. Magellan's voyage was therefore explicitly commercial with religious overtones.

This stands in stark contrast to the voyages of James Cook between 1768 and 1779 . Cook's missions had explicit scientific aims. The first voyage was commissioned by the Royal Society to observe the transit of Venus across the sun from Tahiti. The second voyage's goal was to find the Terra Australis, the mythical southern continent. The third voyage was in search of the Northwest Passage. On all three voyages, Cook brought artists and scientists to record and study all that he found. Since the longitude problem had been solved, Cook was able to accurately fill in the map of the Pacific. His “discoveries” point out how weak European knowledge of the Pacific was at this late date. Many islands were first charted by Cook and his ships made the first European 
circumnavigation of New Zealand. He also claimed the east coast of Australia for Britain.

Unlike Magellan, who was driven to bring Christianity to the natives, Cook had a much more romantic view of the Pacific islanders.

"We debauch their morals already too prone to vice and we introduce among them wants and perhaps diseases which they never before knew and which serves only to disturb that happy tranquility they and their forefathers have enjoyed ... If anyone denies the truth of this assertion let him tell me what the natives of the whole extent of America have gained by the commerce they have had with Europeans.",

Clearly this suggests that islands found and colonized later had a much different experience than those found during the initial period.

\section{Data Description}

The data on island colonization, GDP, and infant mortality are assembled from a large number of sources. Our starting point was a database of islands maintained by the UN. ${ }^{9}$ This dataset provided us with a comprehensive list of individual islands along with nation, population and area. We sorted the islands by population and investigated islands that satisfied two criteria. First, we only included islands that require open ocean sailing to reach them from Europe. Second, we limited the sample to relatively small landmasses, specifically those less than 150,000 square kilometers. These selection criteria are intended to generate a sample of islands that fit our story of random variation in colonial experience. We are particularly interested in the randomness associated with the age of exploration. Islands that were unavoidably found as Europeans made their way down the coast of Africa clearly have a less random history than the islands of the Pacific. The size criterion is intended to make the sample as homogeneous as possible. Large landmasses like Australia are fundamentally different than the islands in our sample. Within the group of islands fitting these criteria we researched islands in order of population using any islands for which data were available.

\footnotetext{
${ }^{8}$ Hough [1994].

${ }^{9}$ http://islands.unep.ch/
} 
Islands that are part of a group are only included as independent data points if there is some independent information for the individual island. For example, the majority of the islands in the Maldives have an identical colonial history and we only have one GDP data point for the entire group. In this case, there is only one island in the Maldives included in our dataset. On the other hand, the islands of the Netherlands Antilles have heterogeneity of both colonial history and GDP, so the individual islands in the group are included separately. We do, however, recognize that these may not be completely independent data points so all the econometric analysis is clustered at the islands group level.

Where available, we obtained GDP per capita for the year 2000 from the United Nations. Per capita GDP figures were available for 39 island nations covering 61 of the islands in our dataset. Roughly 19 islands are possessions of other countries, for example Guam is a US possession. In those cases we obtained island level income per capita and infant mortality numbers for the island from the statistical agency of the relevant country. ${ }^{10}$ In the case of islands that are currently part of an island group (such as the Cook Islands), we disaggregated country level data into the component islands where possible. For example Yap and Pohnpei are both states in the Federated States of Micronesia, but the two islands have different histories, wind patterns, and economic output and are located more than 1,000 miles apart. In some of these cases we were able to obtain separate GDP breakdowns from a series of reports on Pacific island groups produced by the Asian Development Bank. ${ }^{11}$

The colonial and settlement histories for each island come from a myriad of sources. For the Pacific islands we relied heavily in the Pacific Island Yearbook. For Atlantic and Indian Ocean islands, we used Encyclopedia Britannica and supplemented this source

\footnotetext{
${ }^{10}$ In these cases we will be using income per capita as a proxy for GDP per capita. We recognize that this is an imperfect measure. We report robustness checks where we limit ourselves to the GDP data.

${ }^{11}$ We used the breakdowns by island in the following way. The island group level data was used to establish relative income levels. For example, the disaggregated data tells us that Yap in the FSM has twice the per capita income of Moen in the same group. Using the relative income and population data we calculated the per capita income for each island so that the relative income levels were correct and that the population weighted group average was equal to the GDP per capita figure for the group from the UN.
} 
with information from official websites maintained by the governments of each island. We collected the entire history of each island, including the first European sightings, the first settlements, the extent of such settlements, and the political history of the island's colonization if any.

Wind speeds are from satellite data taken from CERSTAT. ${ }^{12}$ The satellites measure wind speeds over water for the entire globe, reported on a one degree longitude latitude grid. The data we utilize are reported monthly and consist of the average wind vector in the north-south direction and the average wind vector in the east-west direction. For our instruments, we use the average and standard deviation of these data points over the year.

Table I contains summary statistics for the data. Thirty nine of the eighty islands are located in the Pacific, thirty five are in the Atlantic and the remainder are in the Indian Ocean. The median population on our islands is about 14,000 people. This ranges from as few as 102 people on Palmerston Island (in the Cook Islands) to more than 11 million people in Cuba. Our results are robust to dropping islands with fewer than 10,000 people. The median land area for the islands is 130 square kilometers. The mean 2000 GDP per capita on the islands in the sample is $\$ 7,953$ with a high of $\$ 53,735$ for Bermuda.

All but one of the islands, Tonga, was a European colony at some point in their history with an average number of years as a colony of over 218 years. However there is a larger group that had relatively limited colonial experience. Twenty four countries in the sample were a colony for one hundred years or less and fourteen for less than fifteen years. In general the Atlantic islands were the first to be colonized by Europeans and some islands including Bonaire, Curacao, and Barbados have 400 years of colonial history.

\footnotetext{
${ }^{12}$ The CERSAT (Centre ERS d'Archivage et de Traitement - French ERS Processing and Archiving Facility) is part of IFREMER (French Research Institute for Exploitation of the Sea. It was created in 1991 as a node of the ESA (European Space Agency) ground segment for the ERS-1 and ERS-2 Earth observation satellites. http://www.ifremer.fr/cersat/
} 
One possible criticism of our approach is that islands tend to be small and have different natural resources than continental nations and are therefore not "real countries" of interest to macroeconomists. Since many successful islands focus on tourism, one could also make the case that this also makes them different from "real" countries. We have several responses to this. First, the islands in the sample have rich variation in their latitudes and levels and types of natural resources. Appendix Table IV shows that agriculture is a large fraction of the economy for islands like Dominica and some of the Federated States of Micronesia like Pohnpei. Bermuda and the Virgin Islands tend to focus on services, though this can mean banking and insurance in addition to tourism. More importantly, even if all the islands in the South Pacific or the Atlantic had beautiful beaches, we still would need to ask why certain islands have a subsistence level of income while others have a standard of living that rivals Sweden and the US. Grand Cayman is a tourist paradise while Hispaniola (Haiti plus the Dominican Republic) is not, despite the fact that both islands have tropical breezes and the beauty of the Caribbean Sea. ${ }^{13}$

\section{Empirical Results}

Figure 1 shows a scatter plot of log GDP per capita versus number of centuries as a colony. The circles are for islands in the Atlantic. The triangles are for islands in the Pacific and the squares are for islands in the Indian Ocean. The regression line shows a clear positive relationship between length of colonial period and modern GDP. While there is a large amount of variation around the regression line (we certainly don't think colonial history explains everything), the t-statistic for the slope is 6.1. The coefficient is 0.41 meaning that every additional 100 years of colonial history is associated with a 41 percent increase in GDP. Remarkably the upward slope holds within each of the oceans. The relationship is not driven simply by the fact that Atlantic islands were discovered by Europeans earliest and are the richest.

\footnotetext{
${ }^{13}$ We are not claiming that the length of the colonial period explains the Grand Cayman Hispaniola income gap but rather that even within Caribbean islands, there is massive and interesting variation in economic performance.
} 
Table II shows five different cross sectional regressions with our basic result. For columns (1) through (5) log GDP per capita is the dependent variable. Column (1) shows the basic correlation illustrated in Figure (1). Higher per capita GDP is associated with a longer period under colonial rule. Each additional hundred years is associated with GDP per capita that is 41 percent higher.

Column (2) adds geographic controls. We include dummies for each ocean and we control for island land area and absolute value of latitude (distance from the Equator). As in Gallup, Sachs and Mellinger [1999] and Sachs [2003], the absolute value of latitude is strongly related to current levels of income. Every 10 degree increase in latitude (i.e. moving roughly 700 miles away from the equator) is associated with a 48 percent increase in GDP. Those authors find that latitude works through the efficiency of agriculture and disease prevalence. Acemoglu et al [2001] provide evidence that latitude's effects work through variation in the nature of European settlements and institutions that were established. Island area is also significant with larger islands doing more poorly than smaller islands. Interestingly, the Pacific and Atlantic Ocean dummies are not significantly different from each other, though the Pacific coefficient is significantly different from the Indian Ocean (the excluded category). Including the geographic controls does not substantially alter the results for colonial tenure.

One important possibility is that Europeans simply chose to settle the best islands first and hence the more successful islands have a longer colonial history. For example, being near a continent could be correlated both with heavy settlement and with current GDP. We are able to reject this explanation for our results by using wind direction and speed as instruments for settlement or length of colonial period. As discussed in a previous section, wind patterns make an appealing instrument because they were incredibly important during 1500-1890 (and determined discovery and settlement), but may have little direct effect on GDP today.

In column (3) we instrument for the number of years as a colony using data on wind speed. Given the direction of travel from Europe, the east-west component of the wind is 
particularly important for sailing voyages. We use the average value for the east-west component of the wind and the monthly standard deviation as instruments. ${ }^{14}$ Column (1) in Appendix I shows the first stage. The instruments are significant predictors of the length of colonial history with a first stage F statistic of 6.0. Each individual instrument is significant. Column (3) of Table I shows the second stage of the two stage least squares regression. The results are statistically indistinguishable from the OLS results and the coefficient on years of colonization remains very significantly away from zero with a t-statistic of 2.8. Each additional hundred years of colonization is associated with 44 percent larger GDP per capita.

One objection to our IV strategy is that the instrument is well suited to describing the beginning of colonial rule, but is not a good instrument for the end of colonial rule. Given that the years of colonial rule is determined by both the beginning and end dates of the colonial period, it seems sensible to examine these separately. A final concern about late colonialism is that our data includes countries which currently have a colonial relationship with a developed country such as Puerto Rico, Guam, or the Netherlands Antilles. It is possible that current transfers from the colonizing country to these islands are important. ${ }^{15}$

Columns (4) and (5) present regressions which use the first and last year of colonialism instead of the total number of years of colonialism. ${ }^{16}$ These regressions also include a dummy to indicate if the country was a colony after 2000. The results indicate that it is the start date of colonialism that is driving our results, not the end date. The coefficient on the beginning year of colonialism is identical in magnitude (but opposite in sign) to the coefficient on the number of years of colonialism in the previous regressions. Being colonized one hundred years later is associated with a $40 \%$ increase in income. The coefficient on the last year of colonialism is well estimated to be near zero. Whether the

\footnotetext{
${ }^{14}$ Appendix II explores the use of other variations on wind speed and direction as instruments. The results are quite similar.

${ }^{15}$ It is not clear that we should be excluding late transfers as part of the colonial legacy. If one aspect of having been a colony in 1800 is that you increase the probability of being a colony in 2000 this should be included as part of the effect of colonialism.

${ }^{16}$ These data are divided by 100 in order to have the coefficients consistent with centuries as a colony.
} 
island was still a colony in 2000, however, is significant and positive. Being a colony in 2000 is associated with $40 \%$ higher income. The inclusion of this dummy has no significant impact on the coefficient on the first or last year of colonialism, suggesting that our base result is not being driven by current transfers. In Column (5) the first year of colonialism is instrumented with wind. The results are statistically identical to the OLS results.

As an additional outcome measure we replace GDP per capital with infant mortality in Columns (6) - (8). These results mirror the results for GDP per capita. The number of centuries that an island was a colony is a negative and significant predictor of infant mortality in all the specifications. One notable difference compared to the GDP columns is the importance of the ocean dummies. The Indian Ocean has significantly higher infant mortality than the Pacific. This result is also robust to our IV strategy.

The regressions in Table III examine whether our results are being driven by sample and data selection. Column (1) repeats our base result. Column (2) excludes islands for which there is no direct GDP data available from the UN. These excluded islands are generally territories of developed countries such Guam and the British Virgin Islands. This column does allow for adjustments to GDP within island groups as described in the data section. Column (3) does not include these adjustments. The results for these three columns are identical, suggesting that our data collection is not driving the results.

Columns (4) through (7) show the results of running our base regression on sub samples of islands limited to the Atlantic and Pacific Oceans. Columns (4) and (5) are estimated with OLS. Columns (6) and (7) instrument the number of centuries of colonialism with wind data as described above. Remarkably, the results are the same for each ocean as they are for the entire sample and in all cases the coefficient on the number of years of colonialism is statistically significant. 


\section{VI.A. Mechanisms}

The island data show a robust relationship between the length of colonization and modern day income. The next question is of course, why should past colonialism in these islands be good for income levels? ${ }^{17}$ Any explanation must allow for events happening centuries ago to matter today. This fact alone points to the importance of institutions, given their longevity. For example the establishment of property rights, courts and a stable government are all likely to be helpful for long run economic performance. Another related possibility is that the Europeans (particularly the missionaries who established many of the earliest settlements) established schools which raised human capital. The colonized islands may have been more able to trade with other islands and other countries following colonization.

This line of thought is hardly new. Acemoglu, Johnson and Robinson argue that certain forms of European settlement set up stable, pro-growth institutions. In particular, they distinguish between the types of colony, with settlement colonies producing positive modern outcomes and extractive colonies producing negative ones. La Porta, Lopez de Silanes, Shleifer and Vishny [1997, 1998] also emphasize an aspect of the quality of colonization, finding that the identity of the colonizer matters through differences in the legal systems. Our initial results emphasize the importance of the quantity of European influence, without reference to the specifics of the colonial regime. This section will ask whether controlling for mechanisms through which colonization may matter diminishes the importance of the length of the colonial experience.

Table IV examines whether any measures of the quality of the colonial experience can diminish the importance of the length of colonial experience. Columns (1) and (2) look at the impact of trade, slavery and democracy. We include in our basic regression a dummy for whether the island engaged in trade in complex products during the colonial period. The dummy variable is positive for islands which only traded in gathered products such as fish or dried coconut during the colonial period. Islands trading in

\footnotetext{
${ }^{17}$ We can't come close to answering this question, but we mention here some of the most plausible reasons discussed in the literature.
} 
organized agriculture (such as sugar), mining, or livestock are coded with a zero. We include a dummy for whether agriculture used imported slaves. We also check the possibility that the length of colonization is associated with greater democratization. We test this by including the year of the first elected legislature as a regressor. Column (3) uses dummies for $19^{\text {th }}$ and $18^{\text {th }}$ century legislatures to check for nonlinearity in this effect.

The point estimates suggest that islands with major trade goods in colonial times have higher modern output by $40-50 \%$. This result is generally statistically insignificant. The inclusion of trade does not diminish the importance of the length of colonization, suggesting that something other than the trade channel is at work. The use of imported slaves is not significantly correlated with income and the point estimate is quite close to zero. Similarly, an early legislature does not appear to be correlated with income. Neither of these controls changes the basic result.

Another potential (and insidious) possibility is that the colonizers of the earlier settled islands wiped out the native population and replaced it with Europeans with higher human capital or more ability to trade. We partially reject this explanation based on the fact that most of the Pacific Islands in our sample still have much of their native population intact. For example, on Guam, one of the most economically successful Pacific islands, 43 percent of the people can trace their roots back to the original Chamorros who inhabited the island and 22 percent of the people are Filipino. In Tahiti, 67 percent of the people are Polynesian and another 17 percent are part Polynesian. Only 10 percent are white.

More formally, we test to see whether the modern ethnic composition of the islands explains differences in output. This ties in nicely with Acemoglu et al, whose work suggests that higher rates of long run settlement are associated with better institutions.

Column (4) of Table IV tests the effect of modern ethnic composition on output along with the length of colonial experience. We find that the modern ethnic composition is significantly correlated with output. The omitted category is Asian and natives, so higher numbers of blacks, whites or mixed race are correlated with higher income. This is 
consistent with the notion that more European influence, in this case in the form of population transfers, leads to higher income. As in Acemoglu et al, settlement colonies appear to do better. The results do not, however, support obvious conclusions about the quality of European influence. The coefficient on percentage white is not significantly different than the coefficient on percentage black.

\section{VI.B. The Identity of the Colonizer and the Timing of the Colonial Experience}

Tables V and VI investigate differences in the quality of colonial experience in a much more basic level. Two different hypotheses are examined. First, does the identity of the colonizer matter? Are years under French significantly different than years under Spanish rule? Second, does the timing of colonialism matter? Is there a difference between years spent as a colony in the $16^{\text {th }}$ century versus the $18^{\text {th }}$ century?

Columns (1) and (2) of Table V ask whether the nation doing the colonizing is related to modern day GDP per capita. Years spent as a colony are included in the regression individually. Given the number of regressors, the individual coefficients are surprisingly well estimated and some conclusions about a ranking of colonizing countries can be made. Perhaps unsurprisingly, a year spent as a US colony is associated with a larger income increase than a year spent under any other country. The difference between the US and the other countries is significant. The Dutch, British and French comprise the second best group and are statistically identical. The Spanish are next with a coefficient that is significantly lower than the Dutch, but not the British and French.

The Portuguese are significantly worse than all the others. They are the only country that shows a significant negative effect of an additional year of colonialism. It should be noted however that this results rests on a base of only two islands (St. Helena in the Atlantic and Huvadu in the Maldives) and that the Portuguese experience was limited to the $17^{\text {th }}$ century and earlier. As we will show shortly, years of early colonialism are not necessarily identical to years of later colonialism. 
The fact that there is no evidence that the British islands are outperforming the French islands is interesting in light of work by LaPorta et al [1996] that show significant differences in performance related to British and French legal systems. The French and the British are not, however, the only countries to adopt these legal systems. For column (2) we group the years of colonization by the legal system of the colonizers. The US and Britain use the British Common law legal system. The Dutch, French, Spanish, and Portuguese use the French Civil law legal system For completeness (and to be consistent with LaPorta et al) we include a category for Japanese and German colonies using the German legal system. We find that there is no significant difference between the three systems.

Table VI examines the question of Magellan versus Cook raised earlier in the paper. Are differences in pre and post enlightenment colonialism evident in our data? Column (1) splits the number of years of colonialism into years before 1700 and years after $1700{ }^{18}$ The results suggest that only the years after 1700 are positively associated with modern outcomes. An additional 100 years of post-1700 colonialism is associated with 64\% higher per capita income. The coefficient is highly significant and significantly different than the coefficient on pre-1700 colonial years. This suggests that the colonial era of Cook was indeed different from that of Columbus and Magellan.

Column (2) breaks the years into three eras, pre-enlightenment, post-enlightenment, and post 1900. Once again, the pre and post enlightenment years are significantly different from each other. The $20^{\text {th }}$ century years are not significantly different from either era. In column (3) we add a dummy for whether an island was a colony in 2000 in order to isolate the effect of transfers from other mechanisms. With this additional control, years of $20^{\text {th }}$ century colonialism become statistically worse than years between 1700 and 1900 . Being a colony at the end of the $20^{\text {th }}$ century remains positively associated with income. This result suggests that decolonization during the $20^{\text {th }}$ century was problematic. Colonies that made it to the end of the century are much better off than countries that did not. Interestingly, the net result of being a colony for the entire $20^{\text {th }}$ century is not

\footnotetext{
${ }^{18}$ The results are robust to moving the cutoff to 1750 .
} 
significantly different than zero. Obviously, conclusions involving decolonization do not fit our natural experiment story since the end of colonialism is almost certainly endogenous. This result must therefore be seen as more of an interesting correlation than causal.

\section{VI.C. A Broader Sample of Countries}

Our results suggest that the length of colonial experience is positively correlated with per capital GDP in a sample of islands. The IV results further suggest that these results are not being driven by the selective colonization of islands that have features conducive to good modern outcomes. Given the similarity of the IV and OLS results, it may be instructive to check the basic results against a larger more traditional sample of countries. Table IV shows the results from regressing per capita GDP against the number of years a country was a colony for a sample of non-island developing countries. This sample is consistent with the countries included in Acemoglu, Johnson, and Robinson.

The basic results match quite nicely with our island results. Each additional century of colonial tenure is associated with a 40 percent increase in GDP. This is not statistically significantly different from the 45 percent coefficient found in the island sample. Including latitude as a control does not significantly change this coefficient. One advantage of using this sample is that standard measures of modern institutional quality can be included. Column (3) of Table IV includes expropriation risk as an additional regressor. Expropriation risk is significant and negative, as expected. This reduces the point estimate on colonial tenure, but it remains large and significant. In column (4) we include the Acemoglu, Johnson and Robinson measure of log settler mortality with similar results.

While the results from this sample are not as well identified as from the islands sample, they are still instructive. The basic relationship appears to extend beyond our island sample. The results are robust to the inclusion of standard modern institutional measures and geographic controls. 


\section{VII.Concluding Remarks}

We have argued for an "islands as experiments" approach where random variation in the colonial experiences of islands can be used to think about the long run effects of colonial history on economic performance. The most interesting fact in our sample is a robust positive relationship between the years of European colonialism and current levels of income. While some of this relationship could be driven by smart selection of islands by colonizers, we suspect that part of the relationship is causal. When we instrument for colonization and settlement using wind patterns, we obtain coefficients on years of colonization that are identical to our OLS results.

While the basic results suggest that longer European colonial exposure is good for the modern inhabitants of the islands in our sample, there are a few interesting caveats that we can introduce. First, there is a discernable pecking order amongst the colonizers. Years under US and Dutch colonial rule are significantly better than years under the Spanish and Portuguese.

Second, later years of colonialism are associated with a much larger increase in modern GDP than years before 1700. These findings are consistent with the Acemoglu et al. result that the quality of the colonial experience is important for modern outcomes. It is not difficult to believe that colonialism in the post-enlightenment era led to more efficient and beneficial institution transfer than colonialism under the encomienda system and its contemporaries. This is not to say that we find the early colonial years to be detrimental to modern GDP - we do not. However, given the human toll on the early natives, it is not unreasonable to think that pre 1700 colonialism should be considered as a net negative. 


\section{References}

Acemoglu, Daron, Simon Johnson, and James A. Robinson. 2001. "The Colonial Origins of Comparative Development: An Empirical Investigation,” American Economic Review 91(5): 1369-401.

Acemoglu, Daron, Simon Johnson, and James A. Robinson. 2002. "Reversal of Fortune: Geography and Development in the Making of the Modern World Income Distribution," Quarterly Journal of Economics 117(4), 1231-1294.

Aldrich, Robert, France and the South Pacific Since 1940, University of Hawaii Press, Honolulu, 1993.

Ashcraft, Norman, Colonialism and Underdevelopment: Processes of Political Economic Change in British Honduras, Teachers College Press, New York, 1973.

Aten, Bettina, Alan Heston and Robert Summers. 2002. Penn World Tables Version 6.1. Center for International Comparisons at the University of Pennsylvania (CICUP).

Banerjee, Abhijit, and Lakshmi Iyer, 2005. "History Institutions and Economic Performance: The Legacy of Colonial Land Tenure Systems in India,” American Economic Review 95(4), 1190-1213.

Barro, Robert J. 1991 “Economic Growth in a Cross-Section of Nations,” Quarterly Journal of Economics 106(2): 407-43.

Beckles, Hilary, A History of Barbados: From Amerindian Settlement to Nation-State, Cambridge University Press, Cambridge, 1990.

Black, Clinton V., The Story of Jamaica from Prehistory to the Present, Collins ClearType Press, London, 1965.

Brett, E. A., Colonialism and Underdevelopment in East Africa: The Politics of Economic Change 1919-1939, NOK Publishers, Ltd., New York, 1973.

Campbell, Gwyn, An Economic History of Imperial Madagascar, 1750-1895: The Rise and Fall of an Island Empire, Cambridge University Press, New York, NY, 2005.

Campbell, I. C., A History of the Pacific Islands, University of California Press, Berkeley, 1989.

Carano, Paul and Pedro C. Sanchez, A Complete History of Guam, Charles E. Tuttle Company, Rutland, VT, 1964.

Carrión, Arturo Morales, Puerto Rico: A Political and Cultural History, W.W. Norton \& Company, Inc., New York, NY, 1983. 
Dietz, James L., Economic History of Puerto Rico: Institutional Change and Capitalist Development, Princeton University Press, Princeton, New Jersey, 1986.

Dominican Republic and Haiti: Country Studies, Richard A. Haggerty (ed.), Federal Research Division, Library of Congress, Washington D.C., 1991.

Douglas, Norman and Ngaire Douglas (eds.), Pacific Islands Yearbook, $17^{\text {th }}$ ed, Fiji Times Ltd., Fiji, 1994.

Dupay, Alex, Haiti in the World Economy: Class, Race, and Underdevelopment Since 1700, Westview Press, Inc., Boulder, Co, 1989.

Fieldhouse, D.K., The West and the Third World: Trade, Colonialism, Dependence and Development, Blackwell Publishers, Oxford, UK, 1999.

Gallup, John Luke; Sachs, Jeffrey D; Mellinger, Andrew D, "Geography and Economic Development." International Regional Science Review, vol. 22, no. 2, August 1999, pp. 179-232.

Glaeser, Edward L., Rafael La Porta, Florencio Lopez-de-Silanes and, Andrei Shleifer, "Do Institutions Cause Growth?," National Bureau of Economic Research Working Paper 10568, June 2004.

Graham, Norman A. and Keith L. Edwards, The Caribbean Basin to the Year 2000: Demographic, Economic, and Resource-Use Trends in Seventeen Countries, Westview Press, Boulder, Colorado, 1984.

Hall, Robert E. and Charles I. Jones "Why Do Some Countries Produce So Much More Output Per Worker Than Others,” Quarterly Journal of Economics, February 1999, 83116.

Hezel, Francis X., Strangers in Their Own Land: A Century of Colonial Rule in the Caroline and Marshall Islands, University of Hawai’i Press, Honolulu, 1995.

Hope, Kempe Ronald, Economic Development in the Caribbean, Praeger Publishers, New York, NY, 1986.

Hough, Richard, Captain James Cook, W.W. Norton \& Company, Inc., New York, 1994

Howard, Rhoda, Colonialism and Underdevelopment in Ghana, Africana Publishing Company, New York, 1978.

Howe, K R, Where the Waves Fall: A New South Sea Islands History from First Settlement to Colonial Rule, University of Hawaii Press, Honolulu, 1984. 
Huxley, Anthony (ed.), Standard Encyclopedia of the World's Oceans and Islands, G.P. Putnam’s Sons, New York, NY, 1962.

Indian Ocean: Five Island Countries, Helen Chapin Metz (ed.), Federal Research Division, Library of Congress, Washington D.C., 1995.

Islands of the Commonwealth Caribbean: A Regional Study, Sandra W. Meditz and Dennis M. Hanratty (eds.), Federal Research Division, Library of Congress, Washington D.C., 1989.

Iyer, Lakshmi. "The Long-Term Impact of Colonial Rule: Evidence from India." Harvard Business School Working Paper, No. 05-041, 2005.

Jiménez de Wagenheim, Puerto Rico: An Interpretive History from Pre-Columbian Times to 1900, Markus Wiener Publishers, Princeton, NJ, 1998.

Knight, Franklin W., The Caribbean: The Genesis of a Fragmented Nationalism, Oxford University Press, New York, 1978.

La Porta, Rafael, Florencio Lopez-de-Silanes, Andrei Shleifer, and Robert Vishny. 1997. “Legal Determinants of External Finance,” Journal of Finance 52(3), 1131-1150.

La Porta, Rafael, Florencio Lopez-de-Silanes, Andrei Shleifer, and Robert Vishny. 1998. “Law and Finance,” Journal of Political Economy 106(6), 1113-1155.

Lyons, Martyn, The Totem and the Tricolour: A Short History of New Caledonia Since 1774, New South Wales University Press, Kensington NSW Australia, 1986.

McArthur, John W. and Jeffrey D. Sachs, "Institutions and Geography: Comment on Acemoglu, Johnson and Robinson (2000),” NBER Working Paper No. 8114, 2000.

Malcolm, George A., The Commonwealth of the Philippines, D. Appleton-Century Company, Inc., New York, 1936.

Maude, H. E., Of Islands and Men: Studies in Pacific History, Oxford University Press, Melbourne, 1969.

Mauro, Paolo. “Corruption and Growth.” Quarterly Journal of Economics, August 1995, 100:3, 681-712.

Newbury, Colin, Tahiti Nui: Change and Survival in French Polynesia 1767-1945, The University Press of Hawaii, Honolulu, 1980.

Pacific Islands, Naval Intelligence Division, Geographical Handbook Series: General Study, Volume I, 1945. 
Pacific Islands, Naval Intelligence Division, Geographical Handbook Series: Eastern Pacific, Volume II, 1943.

Pacific Islands, Naval Intelligence Division, Geographical Handbook Series: Western Pacific (Tonga to Solomon Is.), Volume III, 1944.

Pacific Islands, Naval Intelligence Division, Geographical Handbook Series: Western Pacific (New Guinea and Islands Northward), Volume IV, 1945.

Parsons, James J., San Andrés and Providencia: English-Speaking Islands in the Western Caribbean, University of California Publications in Geography (Vol. 12), University of California Press, Berkeley, 1956.

Philippines: A Country Study, Frederica M. Bunge (ed.), Federal Research Division, Library of Congress, Washington D.C., 1984.

Pons, Frank Moya, The Dominican Republic: A National History, Hispaniola Books, New Rochelle, NY, 1995.

Rodney, Walter, How Europe Underdeveloped Africa, Howard University Press, Washington, D. C., 1974.

Roger, Robert F., Destiny's Landfall: A History of Guam, University of Hawai'i Press, Honolulu, 1995.

Sachs, Jeffrey D., "Institutions Don't Rule: Direct Effects of Geography on Per Capita Income," National Bureau of Economic Research, Inc, NBER Working Papers: 9490, 2003. 


\section{Table I \\ Summary Statistics}

These are summary statistics for the variables in the islands database. See the text for details on variable sources and construction. Islands still without an elected legislature are coded as getting a legislature in 2004.

\begin{tabular}{|c|c|c|c|c|c|}
\hline Variable & Obs & Mean & Std. Dev. & Min & Max \\
\hline Island's GDP per Capita 2000 & 80 & 7,953.38 & $8,909.50$ & 264.00 & $53,735.00$ \\
\hline Log (GDP Capita) & 80 & 8.42 & 1.12 & 5.57 & 10.89 \\
\hline Infant Mortality 2002 & 80 & 18.68 & 15.21 & 4.00 & 79.00 \\
\hline Number of Centuries as a Colony & 80 & 2.18 & 1.54 & 0.00 & 5.11 \\
\hline Northerly Vector of Prevailing Wind & 80 & 0.18 & 1.28 & -1.55 & 4.20 \\
\hline Easterly Vector of Prevailing Wind & 80 & -4.20 & 2.02 & -6.88 & 4.42 \\
\hline No Historical (1500-1820) Off Island & & & & & \\
\hline Trade Except Fish or Coconuts (0-1) & 80 & 0.48 & 0.50 & 0.00 & 1.00 \\
\hline Agriculture Used Imported Slaves & 80 & 0.40 & 0.49 & 0.00 & 1.00 \\
\hline Year of First Elected Legislature & 80 & 1939 & 69 & 1639 & 2004 \\
\hline Had Legislature by 1800 & 80 & 0.08 & 0.27 & 0.00 & 1.00 \\
\hline Had Legislature by 1900 & 80 & 0.14 & 0.35 & 0.00 & 1.00 \\
\hline Percent Current Pop Native & 77 & 49.07 & 45.06 & 0.00 & 100.00 \\
\hline Percent Current Pop White & 77 & 7.86 & 16.06 & 0.00 & 95.88 \\
\hline Percent Current Pop Black & 77 & 23.65 & 36.98 & 0.00 & 95.00 \\
\hline Percent Current Pop Mixed & 77 & 12.60 & 24.05 & 0.00 & 93.20 \\
\hline Number of Centuries British & 80 & 0.86 & 1.23 & 0.00 & 3.95 \\
\hline Number of Centuries French & 80 & 0.40 & 0.82 & 0.00 & 3.69 \\
\hline Number of Centuries Spanish & 80 & 0.38 & 0.95 & 0.00 & 4.05 \\
\hline Ever British & 80 & 0.68 & 0.47 & 0.00 & 1.00 \\
\hline Ever French & 80 & 0.31 & 0.47 & 0.00 & 1.00 \\
\hline Ever Spanish & 80 & 0.25 & 0.44 & 0.00 & 1.00 \\
\hline Absolute Value of Latitude & 80 & 15.66 & 7.71 & 0.50 & 51.92 \\
\hline Island Area (1000s sq km) & 80 & 5.92 & 20.5 & 0.003 & 110.0 \\
\hline Island Population & 70 & 302,720 & $1,394,832$ & 102 & $11,000,000$ \\
\hline Island is in Pacific & 80 & 0.49 & 0.50 & 0.00 & 1.00 \\
\hline Island is in Atlantic & 80 & 0.44 & 0.50 & 0.00 & 1.00 \\
\hline Island is in Indian & 80 & 0.07 & 0.27 & 0.00 & 1.00 \\
\hline
\end{tabular}




\section{Table II \\ Outcomes Regressed on Years of Colonization}

We regress Log GDP per capita and infant mortality on the number of years the island spent as a colony of a European power. Columns (1), (2), (4), (6) and (7) are OLS. Columns (3), (5) and (8) are two stage least squares where we instrument for centuries of colonial rule or the first year as a colony using the 12 month average and standard deviation of the east-west wind speed for each island.

\begin{tabular}{|c|c|c|c|c|c|c|c|c|}
\hline & (1) & (2) & (3) & (4) & (5) & (6) & (7) & (8) \\
\hline & Log GDP & Log GDP & Log GDP & Log GDP & Log GDP & Infant & Infant & Infant \\
\hline & Capita & Capita & Capita - & Capita & Capita- & Mortality & Mortality & Mortality \\
\hline & & & & & & Per 1000 & Per 1000 & $\begin{array}{c}\text { Per } 1000 \text { - } \\
\text { IV }\end{array}$ \\
\hline \multirow{2}{*}{ Number of Centuries a Colony } & 0.413 & 0.450 & 0.441 & & & -2.801 & -2.611 & -10.244 \\
\hline & $(0.065)^{* *}$ & $(0.083)^{* *}$ & $(0.157)^{* *}$ & & & $(1.156)^{*}$ & $(1.259)^{*}$ & $(4.344)^{*}$ \\
\hline \multirow[t]{2}{*}{ First Year a Colony } & & & & -0.396 & -0.545 & & & \\
\hline & & & & $(0.101)^{* *}$ & $(0.232)^{*}$ & & & \\
\hline \multirow{2}{*}{ Final Year A Colony } & & & & 0.014 & 0.007 & & & \\
\hline & & & & $(0.014)$ & $(0.017)$ & & & \\
\hline \multirow[t]{2}{*}{ Remained A Colony in 2000} & & & & 0.800 & 0.732 & & & \\
\hline & & & & $(0.149)^{* *}$ & $(0.206)^{* *}$ & & & \\
\hline \multirow{2}{*}{ Abs(Latitude) } & & 0.048 & 0.048 & 0.039 & 0.042 & & -0.763 & -0.771 \\
\hline & & $(0.011)^{* *}$ & $(0.011)^{* *}$ & $(0.011)^{* *}$ & $(0.013)^{* *}$ & & $(0.211)^{* *}$ & $(0.221)^{* *}$ \\
\hline \multirow[t]{2}{*}{ Area in millions of sq km } & & -21.046 & -20.984 & -20.429 & -23.791 & & 263.524 & 321.185 \\
\hline & & $(3.937)^{* *}$ & $(3.961)^{* *}$ & $(4.707)^{* *}$ & $(6.169)^{* *}$ & & $(149.986)+$ & $(143.722)^{*}$ \\
\hline \multirow[t]{2}{*}{ Island is in Pacific } & & 0.779 & 0.767 & 0.747 & 0.944 & & -7.427 & -18.724 \\
\hline & & $(0.457)+$ & $(0.522)$ & $(0.470)$ & (0.569) & & (9.498) & (13.608) \\
\hline \multirow[t]{2}{*}{ Island is in Atlantic } & & 0.615 & 0.622 & 0.427 & 0.298 & & -7.349 & -1.117 \\
\hline & & $(0.400)$ & $(0.410)$ & $(0.367)$ & $(0.403)$ & & $(8.581)$ & $(8.555)$ \\
\hline \multirow{2}{*}{ Constant } & 7.524 & 6.172 & 6.192 & 13.673 & 16.356 & 24.771 & 41.579 & 60.751 \\
\hline & $(0.166)^{* *}$ & $(0.526)^{* *}$ & $(0.659)^{* *}$ & $(1.942)^{* *}$ & $(4.173)^{* *}$ & $(3.677)^{* *}$ & $(10.898)^{* *}$ & $(18.551)^{* *}$ \\
\hline Observations & 80 & 80 & 80 & 80 & 80 & 80 & 80 & 80 \\
\hline R-squared & 0.320 & 0.578 & 0.578 & 0.642 & 0.630 & 0.080 & 0.353 & 0.082 \\
\hline
\end{tabular}

Robust standard errors in parentheses. We cluster at the island group level since several of the islands (e.g. the Cook Islands and the Federated States of Micronesia) are used as separate observations from a cluster of politically related yet geographically distinct islands.

+ significant at $10 \%$; $*$ significant at $5 \%$;* significant at $1 \%$ 


\section{Table III \\ Comparison of different Samples}

Column (1) is the base sample used in the rest of the paper. Column (2) uses only GDP figures obtained from the UN, but includes disaggregation of islands that are part of a group. Column (3) uses only the raw UN GDP data. Columns (4) and (5) limit the sample to the Pacific and Atlantic Oceans. Columns (6) and (7) are two stage least squares for each ocean where we instrument for centuries of colonial rule using the 12 month average and standard deviation of the east-west wind vector for each island.

\begin{tabular}{|c|c|c|c|c|c|c|c|}
\hline & $\begin{array}{c}(1) \\
\text { Log GDP } \\
\text { per Capita }\end{array}$ & $\begin{array}{c}\text { (2) } \\
\text { Log GDP } \\
\text { per Capita }\end{array}$ & $\begin{array}{c}\text { (3) } \\
\text { Log GDP } \\
\text { per Capita }\end{array}$ & $\begin{array}{c}\text { (4) } \\
\text { Log GDP } \\
\text { per Capita }\end{array}$ & $\begin{array}{c}\text { (5) } \\
\text { Log GDP } \\
\text { per Capita }\end{array}$ & $\begin{array}{c}(6) \\
\text { Log GDP } \\
\text { per Capita }\end{array}$ & $\begin{array}{c}(7) \\
\text { Log GDP } \\
\text { per Capita }\end{array}$ \\
\hline Sample & Base & $\begin{array}{l}\text { UN data - } \\
\text { disaggregated } \\
\text { groups }\end{array}$ & UN data & Pacific & Atlantic & Pacific - IV & Atlantic-IV \\
\hline Number of centuries a colony & $\begin{array}{r}0.450 \\
(0.083)^{* *}\end{array}$ & $\begin{array}{r}0.557 \\
(0.112)^{* *}\end{array}$ & $\begin{array}{r}0.426 \\
(0.110)^{* *}\end{array}$ & $\begin{array}{r}0.522 \\
(0.084)^{* *}\end{array}$ & $\begin{array}{r}0.293 \\
(0.146)^{+}\end{array}$ & $\begin{array}{r}0.470 \\
(0.192)^{*}\end{array}$ & $\begin{array}{r}0.600 \\
(0.235)^{*}\end{array}$ \\
\hline Abs(Latitude) & $\begin{array}{r}0.048 \\
(0.011)^{* *}\end{array}$ & $\begin{array}{r}0.058 \\
(0.013)^{* *}\end{array}$ & $\begin{array}{r}0.064 \\
(0.017)^{* *}\end{array}$ & $\begin{array}{r}0.063 \\
(0.015)^{* *}\end{array}$ & $\begin{array}{r}0.040 \\
(0.017)^{*}\end{array}$ & $\begin{array}{r}0.064 \\
(0.015)^{* *}\end{array}$ & $\begin{array}{r}0.045 \\
(0.015)^{* *}\end{array}$ \\
\hline Area in millions of sq $\mathrm{km}$ & $\begin{array}{r}-21.046 \\
(3.937)^{* *}\end{array}$ & $\begin{array}{r}-21.621 \\
(3.902)^{* *}\end{array}$ & $\begin{array}{r}-22.265 \\
(3.802)^{* *}\end{array}$ & $\begin{array}{r}-20.698 \\
(1.802)^{* *}\end{array}$ & $\begin{array}{r}-21.685 \\
(6.647)^{* *}\end{array}$ & $\begin{array}{r}-19.806 \\
(4.016)^{* *}\end{array}$ & $\begin{array}{r}-22.192 \\
(6.292)^{* *}\end{array}$ \\
\hline Island is in Pacific & $\begin{array}{r}0.779 \\
(0.457)^{+}\end{array}$ & $\begin{array}{r}0.995 \\
(0.690)\end{array}$ & $\begin{array}{r}1.090 \\
(0.576)^{+}\end{array}$ & & & & \\
\hline Island is in Atlantic & $\begin{array}{r}0.615 \\
(0.400)\end{array}$ & $\begin{array}{r}0.499 \\
(0.581)\end{array}$ & $\begin{array}{r}0.415 \\
(0.527)\end{array}$ & & & & \\
\hline Constant & $\begin{array}{r}6.172 \\
(0.526)^{* *}\end{array}$ & $\begin{array}{r}5.701 \\
(0.755)^{* *}\end{array}$ & $\begin{array}{r}5.708 \\
(0.630)^{* *}\end{array}$ & $\begin{array}{r}6.670 \\
(0.284)^{* *}\end{array}$ & $\begin{array}{r}7.465 \\
(0.501)^{* *}\end{array}$ & $\begin{array}{r}6.710 \\
(0.300)^{* *}\end{array}$ & $\begin{array}{r}6.337 \\
(0.924)^{* *}\end{array}$ \\
\hline Observations & 80 & 61 & 61 & 39 & 35 & 39 & 35 \\
\hline R-squared & 0.578 & 0.625 & 0.538 & 0.553 & 0.431 & 0.549 & 0.332 \\
\hline
\end{tabular}

Robust standard errors in parentheses. Standard errors are clustered at the island group level.

+ significant at $10 \%$; * significant at $5 \%$; ** significant at $1 \%$ 


\section{Table IV \\ Possible Mechanisms for GDP - Colonialism Relationship}

\begin{tabular}{|c|c|c|c|c|}
\hline & (1) & (2) & (3) & (4) \\
\hline & Log GDP & Log GDP & Log GDP & Log GDP \\
\hline & Per Capita & Per Capita & Per Capita & Per Capita \\
\hline \multirow[t]{2}{*}{ Number Of Centuries A Colony } & 0.393 & 0.387 & 0.378 & 0.313 \\
\hline & $(0.100)^{* *}$ & $(0.104)^{* *}$ & $(0.103)^{* *}$ & $(0.091)^{* *}$ \\
\hline \multirow{2}{*}{ No Complex Trade Goods During Colonial Period } & -0.435 & & -0.464 & -0.497 \\
\hline & $(0.279)$ & & $(0.282)$ & $(0.291)^{+}$ \\
\hline \multirow[t]{2}{*}{ Mining During Colonial Period } & & 0.492 & & \\
\hline & & $(0.323)$ & & \\
\hline \multirow[t]{2}{*}{ Organized Agriculture During Colonial Period } & & 0.298 & & \\
\hline & & $(0.295)$ & & \\
\hline \multirow[t]{2}{*}{ Livestock During Colonial Period } & & 0.094 & & \\
\hline & & $(0.398)$ & & \\
\hline \multirow[t]{2}{*}{ Agriculture Used Imported Slaves } & 0.115 & & 0.218 & \\
\hline & (0.369) & & (0.388) & \\
\hline \multirow{2}{*}{ Year Of First Elected Legislature } & 0.000 & & & 0.000 \\
\hline & $(0.001)$ & & & $(0.001)$ \\
\hline \multirow{2}{*}{ Had Elected Legislature By 1800} & & & 0.288 & \\
\hline & & & $(0.462)$ & \\
\hline \multirow[t]{2}{*}{ Had Elected Legislature By 1900} & & & -0.470 & \\
\hline & & & (0.399) & \\
\hline \multirow[t]{2}{*}{ Percent White } & & & & 0.016 \\
\hline & & & & $(0.008)^{*}$ \\
\hline \multirow[t]{2}{*}{ Percent Black } & & & & 0.008 \\
\hline & & & & $(0.007)$ \\
\hline \multirow[t]{2}{*}{ Percent Mixed } & & & & 0.018 \\
\hline & & & & $(0.005)^{* *}$ \\
\hline \multirow[t]{2}{*}{ Abs(Latitude) } & 0.044 & 0.047 & 0.045 & 0.042 \\
\hline & $(0.011)^{* *}$ & $(0.014)^{* *}$ & $(0.011)^{* *}$ & $(0.013)^{* *}$ \\
\hline \multirow[t]{2}{*}{ Area in millions of sq km } & -22.389 & -23.420 & -22.125 & -25.058 \\
\hline & $(3.985)^{* *}$ & $(4.658)^{* *}$ & $(3.154)^{* *}$ & $(3.755)^{* *}$ \\
\hline \multirow[t]{2}{*}{ Island is in Pacific } & 0.921 & 0.792 & 0.820 & 1.286 \\
\hline & $(0.430)^{*}$ & $(0.470)^{+}$ & $(0.455)+$ & $(0.412)^{* *}$ \\
\hline \multirow[t]{2}{*}{ Island is in Atlantic } & 0.578 & 0.635 & 0.425 & 0.306 \\
\hline & (0.404) & $(0.384)$ & $(0.410)$ & $(0.400)$ \\
\hline \multirow[t]{2}{*}{ Constant } & 5.549 & 6.145 & 6.621 & 5.696 \\
\hline & $(2.351)^{*}$ & $(0.517)^{* *}$ & $(0.583)^{* *}$ & $(2.214)^{*}$ \\
\hline Observations & 80 & 80 & 80 & 77 \\
\hline R-Squared & 0.600 & 0.598 & 0.608 & 0.686 \\
\hline
\end{tabular}

Robust standard errors in parentheses. Standard errors are clustered at the island group level.

+ significant at $10 \%$; $*$ significant at $5 \%$; ** significant at $1 \%$ 


\section{Table V}

The Effect of Colonialism by Colonizing Countries

\begin{tabular}{|c|c|c|}
\hline & $\begin{array}{c}(1) \\
\text { Log GDP per Capita }\end{array}$ & $\begin{array}{c}(2) \\
\text { Log GDP per Capita }\end{array}$ \\
\hline \multirow[t]{2}{*}{ Centuries US } & 1.498 & \\
\hline & $(0.346)^{* *}$ & \\
\hline \multirow[t]{2}{*}{ Centuries Dutch } & 0.516 & \\
\hline & $(0.083)^{* *}$ & \\
\hline \multirow[t]{2}{*}{ Centuries British } & 0.411 & \\
\hline & $(0.112)^{* *}$ & \\
\hline \multirow[t]{2}{*}{ Centuries French } & 0.410 & \\
\hline & $(0.124)^{* *}$ & \\
\hline \multirow[t]{2}{*}{ Centuries Spanish } & 0.274 & \\
\hline & $(0.089)^{* *}$ & \\
\hline \multirow[t]{2}{*}{ Centuries Portuguese } & -0.894 & \\
\hline & $(0.157)^{* *}$ & \\
\hline \multirow[t]{2}{*}{ Centuries German } & 0.734 & \\
\hline & (1.036) & \\
\hline \multirow[t]{2}{*}{ Centuries Japanese } & -1.097 & \\
\hline & $(0.743)$ & \\
\hline \multirow[t]{2}{*}{ Centuries British Legal } & & 0.319 \\
\hline & & $(0.145)^{*}$ \\
\hline \multirow[t]{2}{*}{ Centuries French Legal } & & 0.391 \\
\hline & & $(0.108)^{* *}$ \\
\hline \multirow[t]{2}{*}{ Centuries German Legal } & & 0.276 \\
\hline & & $(0.544)$ \\
\hline \multirow[t]{2}{*}{ Abs(Latitude) } & 0.048 & 0.048 \\
\hline & $(0.014)^{* *}$ & $(0.014)^{* *}$ \\
\hline \multirow[t]{2}{*}{ Area in millions of sq km } & -18.410 & -21.985 \\
\hline & $(4.957)^{* *}$ & $(3.983)^{* *}$ \\
\hline \multirow[t]{2}{*}{ Island is in Pacific } & 0.672 & 0.695 \\
\hline & $(0.543)$ & $(0.515)$ \\
\hline \multirow[t]{2}{*}{ Island is in Atlantic } & 0.643 & 0.797 \\
\hline & (0.473) & $(0.458)+$ \\
\hline \multirow[t]{2}{*}{ Constant } & 6.264 & 6.369 \\
\hline & $(0.609)^{* *}$ & $(0.586)^{* *}$ \\
\hline Observations & 80 & 80 \\
\hline R-squared & 0.629 & 0.544 \\
\hline
\end{tabular}

Robust standard errors in parentheses. Standard errors are clustered at the island group level.

+ significant at $10 \%$; * significant at $5 \%$; ** significant at $1 \%$ 


\section{Table VI}

The Timing of Colonialism

\begin{tabular}{|c|c|c|c|}
\hline & $\begin{array}{c}(1) \\
\text { Log GDP per } \\
\text { Capita }\end{array}$ & $\begin{array}{c}(2) \\
\text { Log GDP per } \\
\text { Capita }\end{array}$ & $\begin{array}{c}\text { (3) } \\
\text { Log GDP per } \\
\text { Capita }\end{array}$ \\
\hline Centuries a Colony before 1700 & $\begin{array}{r}0.110 \\
(0.169)\end{array}$ & $\begin{array}{r}-0.001 \\
(0.201)\end{array}$ & $\begin{array}{r}-0.032 \\
(0.207)\end{array}$ \\
\hline Centuries a Colony after 1700 & $\begin{array}{r}0.640 \\
(0.112)^{* *}\end{array}$ & & \\
\hline Centuries a Colony 1700-1900 & & $\begin{array}{r}0.930 \\
(0.221)^{* *}\end{array}$ & $\begin{array}{r}0.854 \\
(0.198)^{* *}\end{array}$ \\
\hline Centuries a Colony after 1900 & & $\begin{array}{r}0.208 \\
(0.317)\end{array}$ & $\begin{array}{r}-0.454 \\
(0.452)\end{array}$ \\
\hline Remained a Colony in 2000 & & & $\begin{array}{r}0.839 \\
(0.251)^{* *}\end{array}$ \\
\hline Abs(Latitude) & $\begin{array}{r}0.049 \\
(0.012)^{* *}\end{array}$ & $\begin{array}{r}0.047 \\
(0.011)^{* *}\end{array}$ & $\begin{array}{r}0.030 \\
(0.013)^{*}\end{array}$ \\
\hline Area in millions of sq km & $\begin{array}{r}-19.691 \\
(4.886)^{* *}\end{array}$ & $\begin{array}{r}-22.493 \\
(5.086)^{* *}\end{array}$ & $\begin{array}{r}-20.067 \\
(4.692)^{* *}\end{array}$ \\
\hline Island is in Pacific & $\begin{array}{r}0.946 \\
(0.436)^{*}\end{array}$ & $\begin{array}{r}1.086 \\
(0.422)^{*}\end{array}$ & $\begin{array}{r}0.915 \\
(0.382)^{*}\end{array}$ \\
\hline Island is in Atlantic & $\begin{array}{r}0.622 \\
(0.363)^{+}\end{array}$ & $\begin{array}{r}0.580 \\
(0.351)\end{array}$ & $\begin{array}{r}0.493 \\
(0.317)\end{array}$ \\
\hline Constant & $\begin{array}{r}5.842 \\
(0.528)^{* *}\end{array}$ & $\begin{array}{r}5.881 \\
(0.500)^{* *}\end{array}$ & $\begin{array}{r}6.456 \\
(0.529)^{* *}\end{array}$ \\
\hline $\begin{array}{l}\text { Observations } \\
\text { R-squared }\end{array}$ & $\begin{array}{r}80 \\
0.605 \\
\end{array}$ & $\begin{array}{r}80 \\
0.623 \\
\end{array}$ & $\begin{array}{r}80 \\
0.670 \\
\end{array}$ \\
\hline
\end{tabular}

Robust standard errors in parentheses. Standard errors are clustered at the island group level.

+ significant at $10 \%$; $*$ significant at $5 \%$; ** significant at $1 \%$ 


\section{Table VII}

\section{GDP and Colonialism within Non-island Developing Countries}

We started with the Acemoglu-Robinson-Johnson [2001] database and added our own measure of length of colonial period. We dropped the three island countries that were in AJR and our islands database.

\begin{tabular}{lllll}
\hline \hline & $(1)$ & $(2)$ & $(3)$ & $(4)$ \\
& Log GDP & Log GDP & Log GDP & Log GDP \\
& Per & Per & Per & Per \\
& Capita & Capita & Capita & Capita \\
& 0.401 & 0.358 & 0.287 & 0.232 \\
Number of Centuries a Colony & {$[0.097]^{* *}$} & {$[0.090]^{* *}$} & {$[0.072]^{* *}$} & {$[0.084]^{* *}$} \\
& & 2.952 & 1.406 & 1.825 \\
Abs(Latitude) & & {$[0.883]^{* *}$} & {$[0.746]^{*}$} & {$[0.822]^{*}$} \\
Mean Temperature & & -0.023 & -0.013 & 0.005 \\
& & {$[0.023]$} & {$[0.019]$} & {$[0.021]$} \\
Expropriation Risk & & & 0.404 & \\
& & & {$[0.067]^{* *}$} & \\
Log Settler Mortality (AJR) & & & & -0.403 \\
& & & & {$[0.093]^{* *}$} \\
Constant & 7.276 & 7.344 & 4.873 & 9.034 \\
& {$[0.215]^{* *}$} & {$[0.686]^{* *}$} & {$[0.682]^{* *}$} & {$[0.728]^{* *}$} \\
Observations & 64 & 64 & 64 & 60 \\
R-squared & 0.22 & 0.40 & 0.63 & 0.56 \\
\hline \hline
\end{tabular}

Robust standard errors in parentheses. + significant at 10\%; * significant at 5\%; ** significant at $1 \%$ 


\section{Appendix I \\ IV First Stage Regression and Reduced Form Regression}

Columns (1) and (2) are OLS. Column (1) is the first stage regression using our preferred set of instruments. We regress the islands' number of centuries as a colony on the northerly and easterly vectors of the island's prevailing wind. Column (2) is a reduced form in which we show the direct effect of wind on modern day GDP.

\begin{tabular}{lrr}
\hline \hline & $(1)$ & $(3)$ \\
& Number Of & Log GDP Per \\
Centuries A & Capita \\
Cast-West Vector Of Wind & -0.265 & -0.139 \\
& $(0.081)^{* *}$ & $(0.066)^{*}$ \\
Monthly StDev of East-West Vector & 0.885 & 0.260 \\
& $(0.302)^{* *}$ & $(0.255)$ \\
Area in millions of sq km & 10.983 & -16.278 \\
Abs(Latitude) & $(4.417)^{*}$ & $(4.810)^{* *}$ \\
& 0.020 & 0.060 \\
Island is in Pacific & $(0.016)$ & $(0.014)^{* *}$ \\
& -1.684 & -0.059 \\
Island is in Atlantic & $(0.387)^{* *}$ & $(0.514)$ \\
& 0.760 & 0.768 \\
Constant & $(0.379)^{*}$ & $(0.544)$ \\
& -0.013 & 6.342 \\
Observations & $(0.964)$ & $(0.892)^{* *}$ \\
R-Squared & 80 & 80 \\
F Statistic for Instruments & 0.624 & 0.440 \\
Prob > F = & 5.96 & \\
\hline \hline
\end{tabular}

Robust standard errors in parentheses. Standard errors are clustered at the island group level.

+ significant at $10 \%$; ${ }^{*}$ significant at $5 \%$; ** significant at $1 \%$ 


\section{Appendix II \\ IV Results Using Alternative Sets of Wind Based Instruments}

In addition to specifying the prevailing wind as two vectors per island, we also tried several other measures of wind speed and direction and used these to instrument for an islands' years of colonization. Below are the second stage results and F-statistics for three different types of wind related instruments. Column (1) takes eight compass headings and measures the knots of prevailing wind along each heading and each month. The instrument is the sum of knots*months that the prevailing wind blew on that heading. We use knot*months along headings $2,4,6,8$ as the set of instruments. In column (2) we use simply the knot*months of wind of blowing towards the South West. Wind on this compass heading is the single strongest predictor of an island being discovered and colonized early. In column (3) we perform a similar exercise but limit ourselves to four compass headings and measure the wind as negative if it blew away from a compass heading instead of towards it. In other words, we have only 4 headings but the wind speed can be positive or negative. We use all four points as instruments.

\begin{tabular}{|c|c|c|c|}
\hline & $\begin{array}{c}\text { (1) } \\
\text { Log GDP Capita } \\
\text { (2SLS) }\end{array}$ & $\begin{array}{c}\text { (2) } \\
\text { Log GDP Capita } \\
(2 S L S)\end{array}$ & $\begin{array}{c}\text { (3) } \\
\text { Log GDP Capita } \\
\text { (2SLS) }\end{array}$ \\
\hline Number Centuries a Colony & $\begin{array}{r}1.038 \\
(0.309)^{* *}\end{array}$ & $\begin{array}{r}0.827 \\
(0.499)\end{array}$ & $\begin{array}{r}0.703 \\
(0.302)^{*}\end{array}$ \\
\hline Area in $1000 \mathrm{~s} \mathrm{Sq}$ & -25.488 & -23.900 & -22.959 \\
\hline Miles & $(4.886) * *$ & $(5.220)^{* *}$ & $(4.153)^{* *}$ \\
\hline Abs(Latitude) & $\begin{array}{r}0.048 \\
(0.013)^{* *}\end{array}$ & $\begin{array}{r}0.048 \\
(0.011)^{* *}\end{array}$ & $\begin{array}{r}0.048 \\
(0.011)^{* *}\end{array}$ \\
\hline Island is in Pacific & $\begin{array}{r}1.649 \\
(0.715)^{*}\end{array}$ & $\begin{array}{r}1.338 \\
(0.876)\end{array}$ & $\begin{array}{r}1.154 \\
(0.650)^{+}\end{array}$ \\
\hline Island is in Atlantic & $\begin{array}{r}0.135 \\
(0.532)\end{array}$ & $\begin{array}{r}0.307 \\
(0.612)\end{array}$ & $\begin{array}{r}0.408 \\
(0.467)\end{array}$ \\
\hline Constant & $\begin{array}{r}4.695 \\
(0.998)^{* *}\end{array}$ & $\begin{array}{r}5.223 \\
(1.375)^{* *}\end{array}$ & $\begin{array}{r}5.536 \\
(0.918)^{* *}\end{array}$ \\
\hline Observations & 80 & 80 & 80 \\
\hline R-squared & 0.282 & 0.456 & 0.523 \\
\hline F Statistic for Instruments in & 4.48 & 2.52 & 1.81 \\
\hline $\begin{array}{l}\text { First Stage } \\
\text { Prob }>\mathrm{F}=\end{array}$ & 0.0032 & 0.118 & 0.139 \\
\hline
\end{tabular}




\section{Appendix III}

List of Islands in Our Dataset

\begin{tabular}{|c|c|c|c|c|c|}
\hline Island & Group/Country & Other Country & $\begin{array}{r}\text { Year First } \\
\text { Sighted }\end{array}$ & $\begin{array}{r}\text { Number of } \\
\text { Years } \\
\text { Colonized }\end{array}$ & $\begin{array}{r}\text { GDP per } \\
\text { Capita }\end{array}$ \\
\hline Aitutaki & Cook Islands & & 1789 & 13 & 2,814 \\
\hline Andros, North & Bahamas & & 1492 & 479 & 14,296 \\
\hline Anguilla & Anguilla & & 1493 & 354 & 9,617 \\
\hline Antigua & Antigua and Barbuda & & 1493 & 349 & 7,653 \\
\hline Ascension & Ascension & United Kingdom & 1501 & 82 & 24,514 \\
\hline Atiu & Cook Islands & & 1777 & 13 & 1,930 \\
\hline Barbados & Barbados & & 1510 & 384 & 9,739 \\
\hline Bermuda & Bermuda & & 1503 & 395 & 53,735 \\
\hline Bonaire & Netherlands Antilles & Netherlands & 1499 & 478 & 15,931 \\
\hline Cuba & Cuba & & 1492 & 389 & 2,535 \\
\hline Curacao & Netherlands Antilles & Netherlands & 1499 & 492 & 15,931 \\
\hline Dominica & Dominica & & 1493 & 246 & 3,484 \\
\hline East Falkland & East Falkland & United Kingdom & 1592 & 231 & 24,514 \\
\hline Efate & Vanuatu & & 1606 & 186 & 1,164 \\
\hline Fefan & Federated States of Micronesia & & 1687 & 101 & 1,335 \\
\hline Funafuti & Tuvalu & & 1819 & 62 & 1,204 \\
\hline Futuna & Futuna & France & 1616 & 117 & 21,776 \\
\hline Grand Cayman & Grand Cayman & & 1503 & 369 & 34,173 \\
\hline Grande Comore & Comoros & & 1505 & 88 & 264 \\
\hline Grande Terre & Guadeloupe & & 1493 & 376 & 7,900 \\
\hline Grenada & Grenada & & 1498 & 344 & 3,440 \\
\hline Guam & Guam & United States & 1521 & 443 & 34,364 \\
\hline Hispaniola DOM & Dominican Republic & & 1492 & 313 & 3,029 \\
\hline Hispaniola HTI & Haiti & & 1492 & 331 & 485 \\
\hline Huvadu & Huvadu & & 1558 & 335 & 2,151 \\
\hline Jamaica & Jamaica & & 1494 & 168 & 3,056 \\
\hline Kadavu & Fiji & & 1789 & 95 & 2,031 \\
\hline Kosrae & Federated States of Micronesia & & 1688 & 101 & 2,751 \\
\hline Lifou & Loyalty Islands & New Caldonia & 1774 & 231 & 12,455 \\
\hline Luzon & Philippines & & 1521 & 297 & 1,002 \\
\hline Mahe & Seychelles & & 1502 & 220 & 7,764 \\
\hline Majuro & Marshall Islands & & 1526 & 100 & 1,896 \\
\hline Malaita & Solomon Islands & & 1568 & 86 & 791 \\
\hline Mangaia & Cook Islands & & 1777 & 13 & 2,171 \\
\hline Mangareva & Gambier Is & French Polynesia & 1687 & 124 & 13,955 \\
\hline Manihiki & Cook Islands & & 1822 & 13 & 2,895 \\
\hline Martinique & Martinique & France & 1502 & 226 & 21,776 \\
\hline Mauke & Cook Islands & & 1823 & 13 & 2,493 \\
\hline Mauritius & Mauritius & & 1507 & 359 & 3,839 \\
\hline Mayotte & Mayotte & France & 1529 & 161 & 21,776 \\
\hline
\end{tabular}




\section{Appendix III}

List of Islands in Our Dataset (continued)

\begin{tabular}{|c|c|c|c|c|c|}
\hline Island & Group & Other Country & $\begin{array}{r}\text { Year First } \\
\text { Sighted }\end{array}$ & $\begin{array}{r}\text { Number of } \\
\text { Years } \\
\text { Colonized }\end{array}$ & $\begin{array}{r}\text { GDP per } \\
\text { Capita }\end{array}$ \\
\hline Mitiaro & Cook Islands & & 1823 & 13 & 2,734 \\
\hline Moen & Federated States of Micronesia & & 1528 & 87 & 1,335 \\
\hline Montserrat & Montserrat & & 1493 & 372 & 8,919 \\
\hline Nauru & Nauru & & 1798 & 78 & 2,702 \\
\hline New Britain & Bismarck Archipelago & Papua New Guinea & 1616 & 61 & 729 \\
\hline New Caledonia & New Caledonia & & 1774 & 231 & 12,455 \\
\hline Niue & Niue & & 1774 & 1 & 3,600 \\
\hline North Caicos & Turks and Caicos Islands & United Kingdom & 1512 & 238 & 24,514 \\
\hline Oreor & Palau & & 1710 & 120 & 6,076 \\
\hline Palmerston & Cook Islands & & 1774 & 13 & 2,493 \\
\hline Penrhyn & Cook Islands & & 1788 & 13 & 989 \\
\hline Pohnpei & Federated States of Micronesia & & 1689 & 101 & 2,711 \\
\hline Puerto Rico & Puerto Rico & & 1493 & 511 & 18,047 \\
\hline Pukapuka & Cook Islands & & 1595 & 13 & 724 \\
\hline Rakahanga & Cook Islands & & 1606 & 13 & 1,528 \\
\hline Rarotonga & Cook Islands & & 1789 & 13 & 6,433 \\
\hline Reunion & Reunion & & 1513 & 341 & 6,200 \\
\hline Rurutu & Austral Islands & French Polynesia & 1769 & 236 & 13,955 \\
\hline Saba & Netherlands Antilles & Netherlands & 1493 & 372 & 15,931 \\
\hline Saipan & Northern Mariana Islands & United States & 1521 & 440 & 12,500 \\
\hline Sint Maartin & Netherlands Antilles & France & 1493 & 356 & 16,000 \\
\hline St Croix & US Virgin Islands & United States & 1493 & 250 & 11,868 \\
\hline St Eustatius & Netherlands Antilles & Netherlands & 1493 & 375 & 15,931 \\
\hline St Helena & St Helena & United Kingdom & 1502 & 494 & 24,514 \\
\hline St John & US Virgin Islands & United States & 1493 & 250 & 18,012 \\
\hline St Kitts & St. Kitts and Nevis & & 1493 & 360 & 8,132 \\
\hline St Lucia & St Lucia & & 1500 & 481 & 4,424 \\
\hline St Martin & Netherlands Antilles & Netherlands & 1493 & 356 & 21,776 \\
\hline St Thomas & US Virgin Islands & United States & 1493 & 250 & 14,061 \\
\hline St Vincent & St Vincent and the Grenadines & & 1498 & 299 & 2,891 \\
\hline Tahiti & Society Islands & French Polynesia & 1767 & 208 & 13,955 \\
\hline Tahuata & Marquesas & French Polynesia & 1595 & 5 & 13,955 \\
\hline Tarawa & Kiribati - Line Islands & & 1788 & 66 & 538 \\
\hline Tol & Federated States of Micronesia & & 1528 & 101 & 1,335 \\
\hline Tongatapu & Tonga & & 1643 & 0 & 1,430 \\
\hline Tortola & British Virgin Islands & United Kingdom & 1493 & 356 & 33,671 \\
\hline Trinidad & Trinidad and Tobago & & 1498 & 289 & 6,347 \\
\hline Tristan da Cunha & Tristan da Cunha \& Gouh & United Kingdom & 1506 & 188 & 24,514 \\
\hline Tutuila & American Samoa & United States & 1787 & 175 & 34,364 \\
\hline Yap & Federated States of Micronesia & & 1686 & 101 & 2,751 \\
\hline
\end{tabular}




\section{Appendix IV \\ GDP by Sector}

This is for a subsample of islands in the database. Source is CIA World Factbook 2002, which in turn uses both UN Data and national government statistics from the relevant countries.

\begin{tabular}{llllll}
\hline \hline island & ocean & GDP & Agriculture & Industry & Services \\
Bermuda & Atlantic & $36 \mathrm{~B}$ & $1 \%$ & $10 \%$ & $89 \%$ \\
Grand Cayman & Atlantic & $1.27 \mathrm{~B}$. & $1 \%$ & $3 \%$ & $95 \%$ \\
Jamaica & Atlantic & $10.21 \mathrm{~B}$. & $6 \%$ & $24 \%$ & $70 \%$ \\
Anguilla & Atlantic & $104 \mathrm{Mill}$ & $4 \%$ & $18 \%$ & $78 \%$ \\
New Britain & Pacific & $11.4 \mathrm{~B}$. & $32 \%$ & $36 \%$ & $32 \%$ \\
Majuro & Pacific & $115 \mathrm{Mill}$ & $14 \%$ & $16 \%$ & $70 \%$ \\
Mauritius & Indian & $13.85 \mathrm{~B}$. & $6 \%$ & $33 \%$ & $61 \%$ \\
US Virgin Islands & Atlantic & $2.4 \mathrm{~B}$. & $1 \%$ & $19 \%$ & $80 \%$ \\
Tongatapu & Pacific & $236 \mathrm{Mill}$ & $26 \%$ & $12 \%$ & $62 \%$ \\
Pohnpei & Pacific & $277 \mathrm{Mill}$ & $50 \%$ & $4 \%$ & $46 \%$ \\
Montserrat & Atlantic & $29 \mathrm{Mill}$ & $5 \%$ & $14 \%$ & $81 \%$ \\
New Caledonia & Pacific & $3.158 \mathrm{~B}$. & $5 \%$ & $30 \%$ & $65 \%$ \\
Guam & Pacific & $3.2 \mathrm{~B}$. & $7 \%$ & $15 \%$ & $78 \%$ \\
Cuba & Atlantic & $31.59 \mathrm{~B}$. & $8 \%$ & $35 \%$ & $58 \%$ \\
British Virgin Islands & Atlantic & $320 \mathrm{Mill}$ & $2 \%$ & $6 \%$ & $92 \%$ \\
St Vincent & Atlantic & $339 \mathrm{Mill}$ & $10 \%$ & $26 \%$ & $64 \%$ \\
Dominica & Atlantic & $380 \mathrm{Mill}$ & $18 \%$ & $24 \%$ & $58 \%$ \\
Barbados & Atlantic & $4.496 \mathrm{~B}$. & $6 \%$ & $16 \%$ & $78 \%$ \\
Grenada & Atlantic & $440 \mathrm{Mill}$ & $8 \%$ & $24 \%$ & $68 \%$ \\
Kadavu & Pacific & $5.007 \mathrm{~B}$. & $17 \%$ & $22 \%$ & $61 \%$ \\
Martinique & Atlantic & $6.117 \mathrm{~B}$. & $6 \%$ & $11 \%$ & $83 \%$ \\
Puerto Rico & Atlantic & $65.28 \mathrm{~B}$. & $1 \%$ & $42 \%$ & $57 \%$ \\
Antigua & Atlantic & $750 \mathrm{Mill}$ & $4 \%$ & $19 \%$ & $77 \%$ \\
Tarawa & Pacific & $79 \mathrm{Mill}$ & $30 \%$ & $7 \%$ & $63 \%$ \\
Malaita & Pacific & $800 \mathrm{Mill}$ & $42 \%$ & $11 \%$ & $47 \%$ \\
St Lucia & Atlantic & $866 \mathrm{Mill}$ & $7 \%$ & $20 \%$ & $73 \%$ \\
Reunion & Indian & $9.387 \mathrm{~B}$. & $8 \%$ & $19 \%$ & $73 \%$ \\
\hline \hline
\end{tabular}




\section{Figure 1 \\ GDP Per Capita versus Years of Colonialism}

Circles represent islands in the Atlantic, triangles are islands in the Pacific and squares are islands in the Indian Ocean.

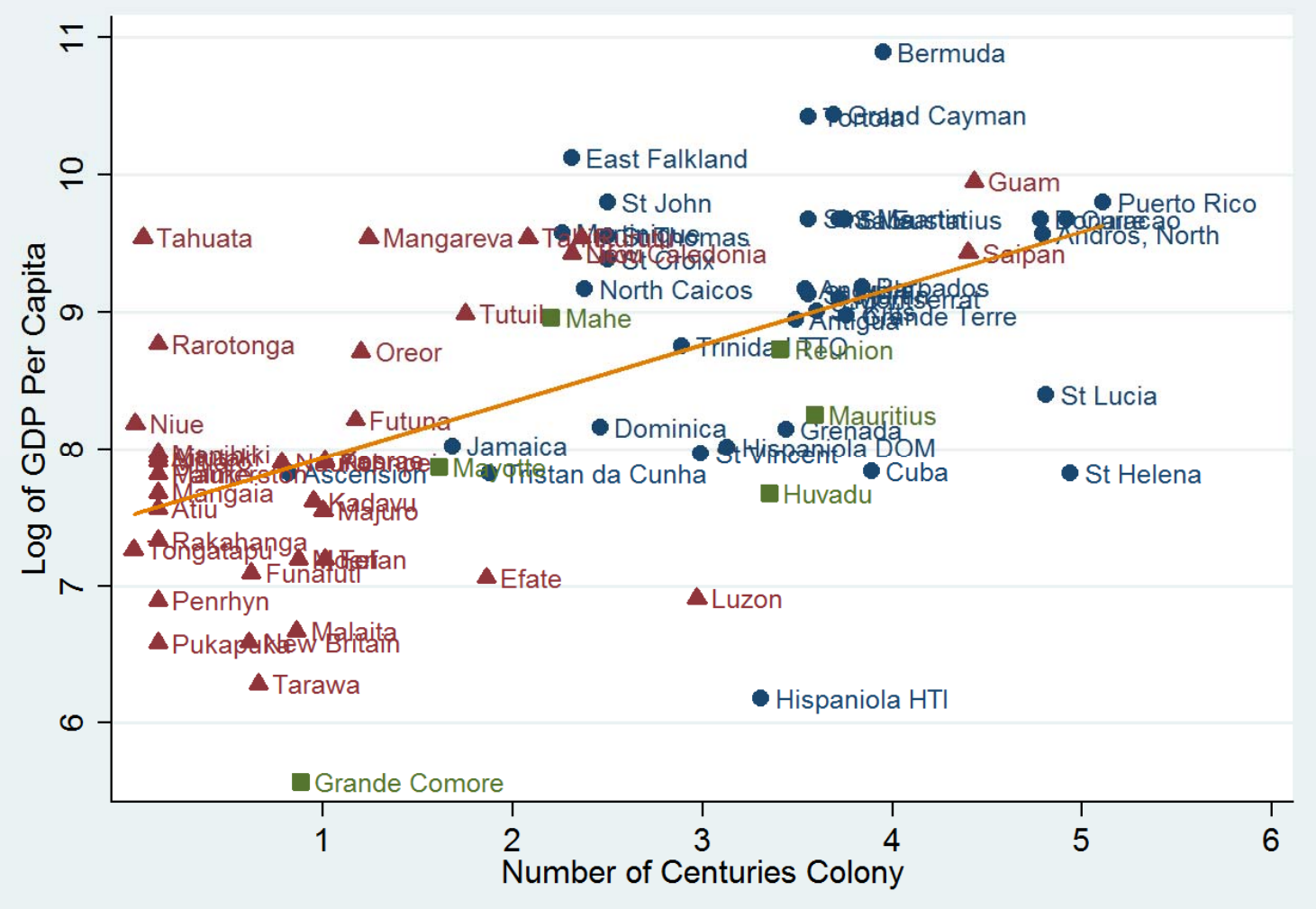


Figure 2

Years of Colonialism Versus Easterly Vector of Wind

Circles represent islands in the Atlantic, triangles are islands in the Pacific and squares are islands in the Indian Ocean.

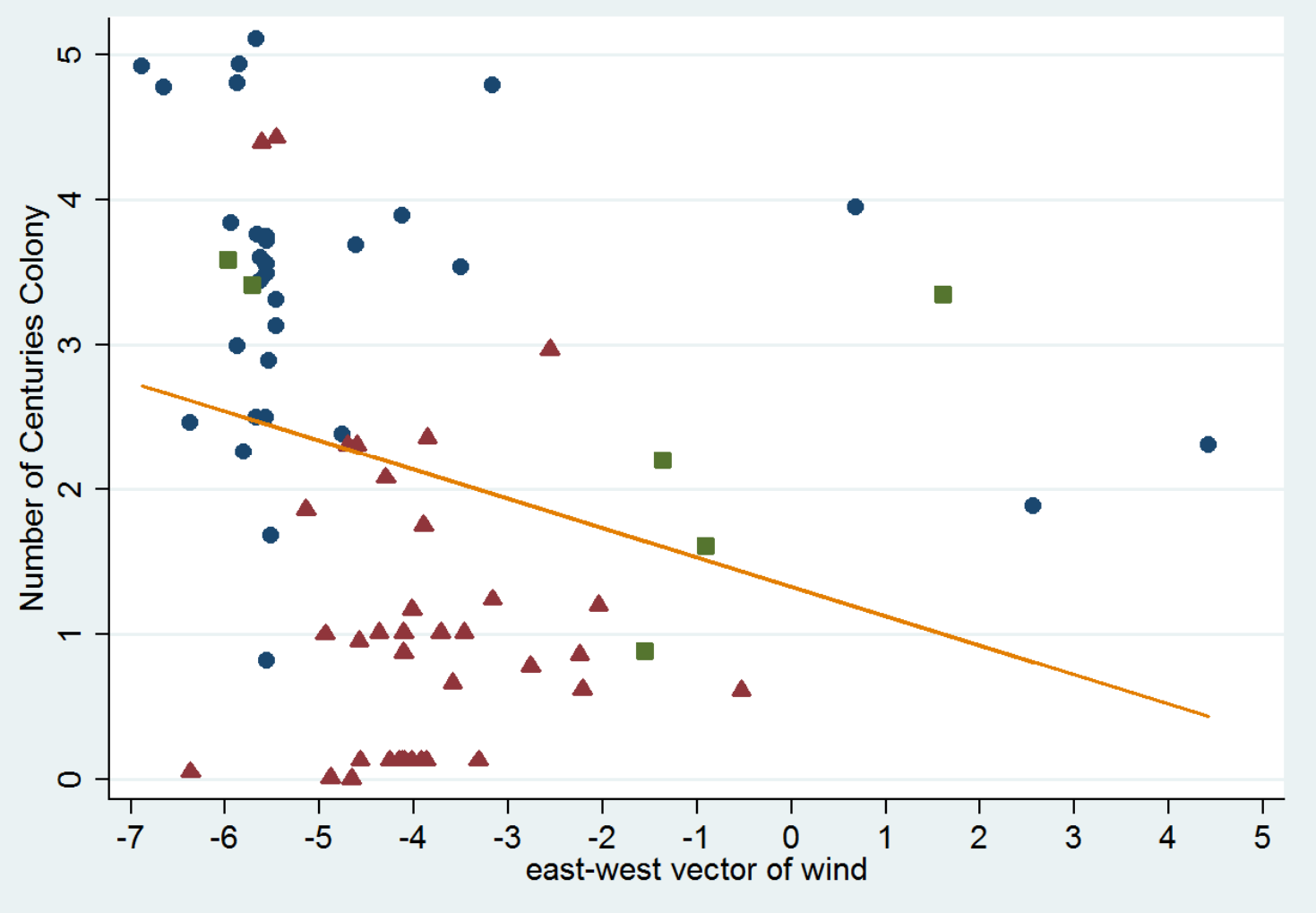

